\title{
Recent dynamics and condition of coral reefs in the Colombian Caribbean
}

\author{
Alberto Rodríguez-Ramírez ${ }^{1}$, María Catalina Reyes-Nivia ${ }^{1}$, Sven $_{Z} \mathrm{Za}^{2}$, Raúl Navas-Camacho ${ }^{1}$, \\ Jaime Garzón-Ferreira ${ }^{1,5}$, Sonia Bejarano ${ }^{3}$, Pilar Herrón ${ }^{4}$ \& Carlos Orozco $^{4}$ \\ 1. Instituto de Investigaciones Marinas y Costeras INVEMAR, Punta de Betín, Zona Portuaria, Santa Marta, Colombia; \\ betorod@invemar.org.co \\ 2. Departamento de Biología (Sede Bogotá) y Centro de Estudios en Ciencias del Mar-CECIMAR (Sede Caribe), \\ Universidad Nacional de Colombia, Punta de Betín, Zona Portuaria, Santa Marta, Colombia; sezeas@unal.edu.co; \\ szea@invemar.org.co \\ 3. University of Exeter, Prince of Wales Road, Exeter Devon, EX4 4PS, UK; sb277@exeter.ac.uk \\ 4. Corporación para el Desarrollo Sostenible del Archipiélago de San Andrés, Providencia y Santa Catalina CORALINA, \\ Vía San Luis, Bight, Km 26, San Andrés, Colombia. \\ 5. Present address: Brewster Academy, 80 Academy Drive, Wolfeboro, NH 03894; anisotremus@gmail.com
}

\author{
Received 31-VIII-2009. C Corrected 09-XI-2009. Accepted 15-XII-2009.
}

\begin{abstract}
Long-term monitoring data provide a basis to recognize changes in coral reef communities and to implement appropriate management strategies. Unfortunately, coral reef dynamics have been poorly documented at any temporal scale in the Southern Caribbean. Through the "National Monitoring System of Coral Reefs in Colombia" (Spanish acronym: SIMAC), we assessed 32 permanent plots at different depth levels in six reefs areas of the Colombian Caribbean from 1998 to 2004. Temporal trends in coral and algal cover were evaluated by repeated measures ANOVA. The model included the effect of depth levels (a fixed effect), monitoring plots (a random effect) as a nested factor within depths, and time (repeated factor). We found high spatial variability in major benthic components. Overall means indicated that algae were the most abundant biotic component in nearly all areas, ranging from $30.3 \%$ at Rosario to $53.3 \%$ at San Andrés. Live coral cover varied considerably from $10.1 \%$ at Santa Marta up to $43.5 \%$ at Urabá. Coral and algae cover per se are not always accurate reef indicators and therefore they need supplementary information. Temporal analyses suggested relative stability of coral and algal cover along the study but the causes for the observed trends were rarely identified. A significant decrease $(\mathrm{p}=0.042)$ in coral cover was only identified for some monitoring plots in Tayrona-time $\mathrm{x}$ plot (depth level) interaction, and importantly, few coral species explained this trend. Significant increase $(\mathrm{p}=0.005)$ in algal cover was observed over time for most plots in Rosario. Temporal trajectories in algal cover were influenced by depth-significant time $x$ depth interaction-in San Andrés (increase, $p=0.004$ ) and Urabá (decrease, $p=0.027$ ). Algae trends were mainly explained by changes in algal turfs. Monitoring programs must focus on the mechanisms mediating the changes, in particular those concerning coral recovery and reef resilience in the current context of climate change. Rev. Biol. Trop. 58 (Suppl. 1): 107-131. Epub 2010 May 01.
\end{abstract}

Key words: Monitoring, coral reef, condition, dynamics, SIMAC, Colombian Caribbean.

Historical analyses support that most of the reefs around the world were degraded before 1900 (Pandolfi et al. 2003). Nevertheless, during the last three decades in the past century, Caribbean reefs have been facing unprecedented changes on geological timescales (Aronson \& Precht 1997, Aronson et al. 2004, Pandolfi \& Jackson 2006). An unequivocal sign of these changes is the loss of coral cover which was estimated around 5\% per year until 2001 (Gardner et al. 2003, Côté et al. 2005). Multiple natural and anthropogenic disturbances such as coastal development (Hallock et al. 1993, Bak \& Nieuwland 1995, Guzman \& Jackson 2008), bleaching events and hurricanes (Edmunds 2002, Hughes et al. 2003, Buddemeier et al. 2004, Gardner et al. 2005, Somerfield et al. 2008) and coral diseases 
(Aronson \& Precht 1997, 2001, Garzón-Ferreira et al. 2001, Sutherland et al. 2004) among others have contributed to coral reductions. Algae have become more abundant on many reefs across the Caribbean as a result of coral mortality (McClanahan et al. 1999, Williams et al. 2001) and reduced herbivory (Hughes 1994, Hughes et al. 1999, Williams \& Polunin 2001, Mumby et al. 2006). Thus, coral decline and algal increase appear to be the most conspicuous features of coral dynamics in recent times.

Natural and anthropogenic factors have contributed to coral decline during the last decades in Colombia (Garzón-Ferreira \& Díaz 2003). Noticeable degradation has been observed on oceanic reefs and remote atolls (Garzón-Ferreira \& Kielman 1994, Zea et al. 1998, Garzón-Ferreira et al. 2005) as well as in continental complexes and fringing reefs (Acosta 1994, Díaz et al. 2000b, Martínez $\&$ Acosta 2005). In the last few decades for instance, live coral cover declined more than $50 \%$ on the oceanic island of San Andrés, while Acropora spp. lost about $80-90 \%$ on the mainland coast at Islas del Rosario (GarzónFerreira \& Kielman 1994, Garzón-Ferreira \& Díaz 2003). Evaluations on the structure of coral communities showed that algae have been the predominant biotic component (DiazPulido et al. 2004, Rodríguez-Ramírez et al. 2006, 2008a). Modern natural disturbances in Colombian Caribbean reefs include hurricanes, bleaching events, epidemic diseases and algae proliferation, although some of these may also be the indirect result of human activities. Anthropogenic disturbances comprise sedimentation, eutrophication, chemical pollution, overfishing, dynamite fishing, nautical activities and coral mining. (Garzón-Ferreira \& Díaz 2003).

Similar to other Caribbean localities, the most dramatic changes on coral reefs across the Colombian Caribbean were documented between the late 1970's until the 1990's. Nevertheless, most of the information from this time period is fragmentary and many changes remain unexplained. As a consequence, monitoring programs and particular studies have devoted to fulfill the lack of information on the origins, extent and progress of reef degradation. Recent outcomes have registered differential trajectories for Caribbean reefs, varying from a continuous and overall trend of decline (Gardner et al. 2003, Côté et al. 2005) to a relative stability and/or insignificant recovery at local scales (CARICOMP et al. 2002, Rogers \& Miller 2006, Edmunds \& Elahi, 2007, Somerfield et al. 2008). Because of the variability in coral reef responses, a better understanding of the recent dynamics of Caribbean coral reefs require further research efforts to support appropriate conservation strategies.

In this paper we present the first attempt to analyze on spatio-temporal scales the information gathered by SIMAC monitoring program ("Sistema Nacional de Monitoreo de Arrecifes Coralinos en Colombia") between 1998 and 2004. We aimed to identify the reef condition, overall spatial patterns of benthic components, and temporal variations in algal and coral cover at six Caribbean reef areas. This analysis also provides insights on local dynamics of coral reefs after major changes were registered across the Colombian reefs. Based on the findings of this research, we outline some recommendations for the long-term reef monitoring programs.

\section{MATERIALS AND METHODS}

Study areas: The monitoring was carried out on six reef areas in the Colombian Caribbean: 1-Tayrona, 2-San Andrés, 3-Rosario, 4-San Bernardo, 5-Urabá and 6-Santa Marta. For each area, one to three depth levels were assessed: shallow (3-6m), mid-depth (9-12m) and deep (15-18m). For each depth level two or three reef sites (monitoring plots, see data analysis) were permanently established (Table 1). Tayrona, Rosario and San Andrés included monitoring plots at three depths, San Bernardo and Urabá had shallow and mid-depth, and at Santa Marta only the mid-depth was monitored. General environmental conditions, coral reef characteristics and site locations are 


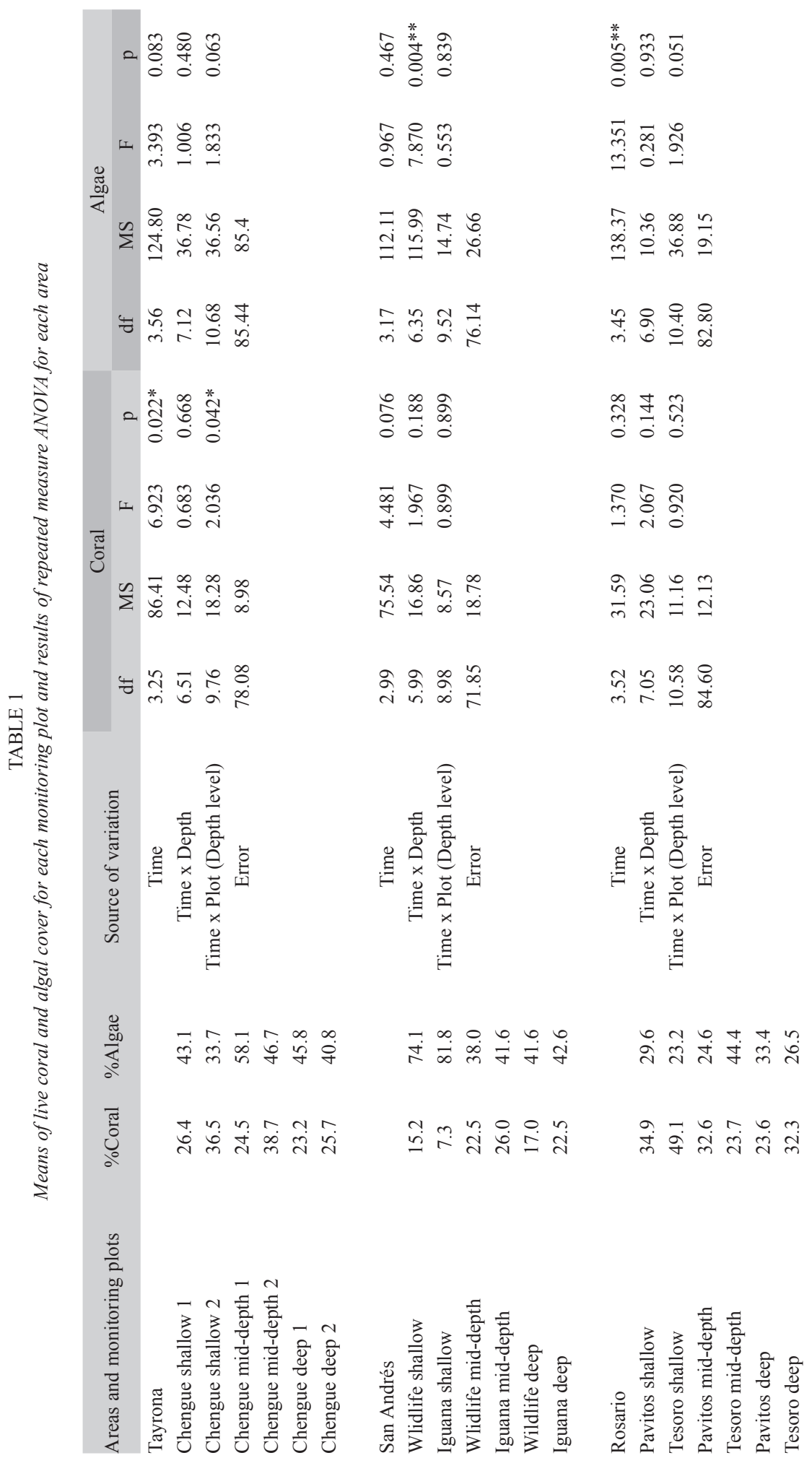




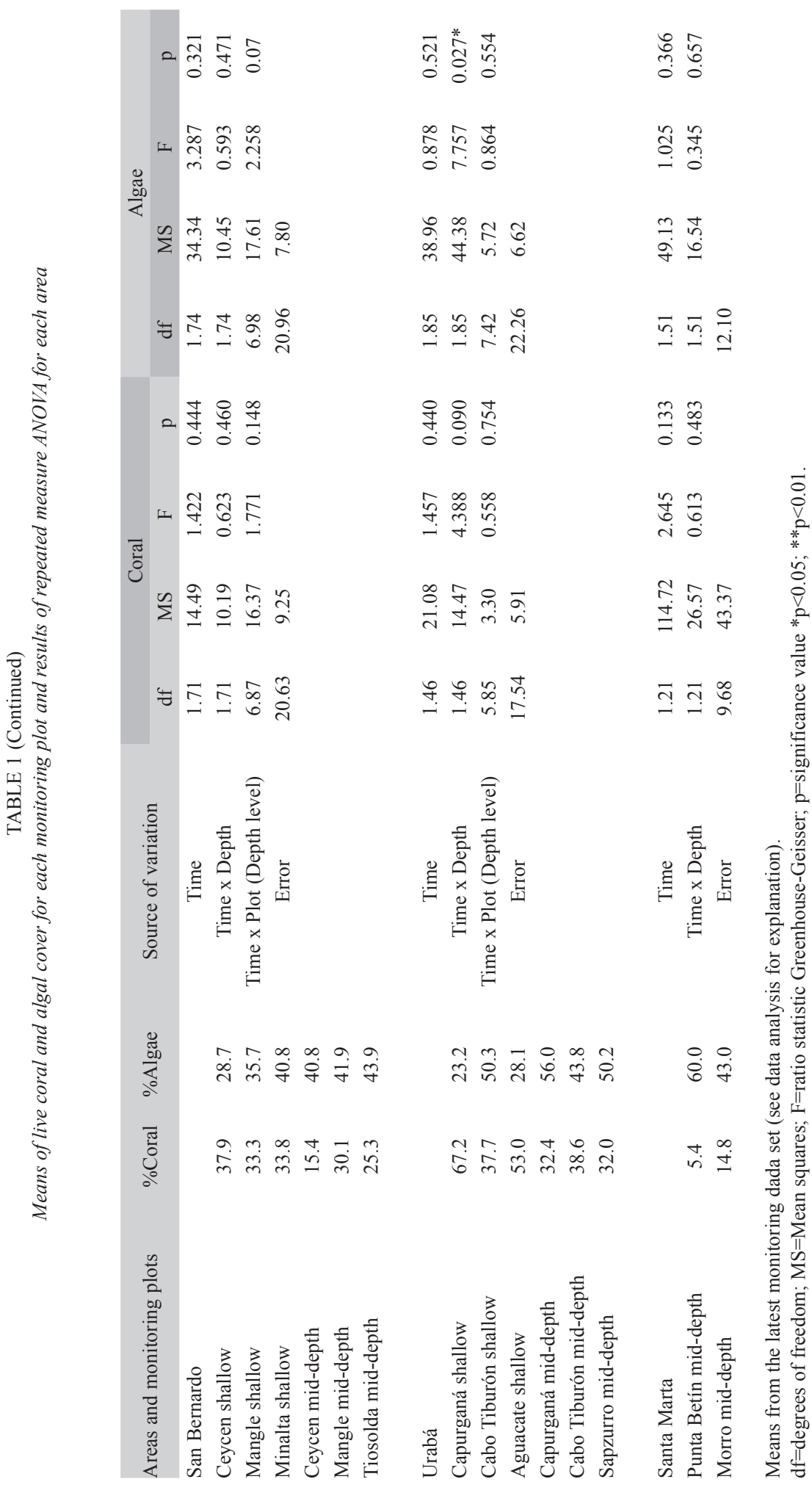


described by Garzón-Ferreira \& RodríguezRamírez (2010).

Sampling: Most of the reef areas were surveyed annually from 1998 to 2004 (see Table 1 in Garzón-Ferreira \& Rodríguez-Ramírez 2010), at approximately the same time each year. Information was gathered following the SIMAC protocol (Garzón-Ferreira et al. 2002) which is based on the CARICOMP methodology (CARICOMP 2001). The cover of benthic substrate was estimated using a light chain $10 \mathrm{~m}$ long over three to five permanent transects per monitoring plot (see Table 1 in Garzón-Ferreira \& Rodríguez-Ramírez 2010). Hard corals were identified at the lowest taxonomic level (genus or species). Steel stakes were fixed at the beginning and end of each transect so that transects could be relocated each year.

Data analysis: In order to determine the current state for each area and to assess the spatial patterns in terms of coral and algal cover (turf, fleshy, encrusting and calcareous), the following means were calculated using only the latest monitoring data set: a) Monitoring plot=averaging transects; b) Depth level=averaging mean values of the monitoring plots located at the same depth level; c) Overall=averaging mean values of all plots. For Tayrona, San Andrés and Rosario, data obtained at the shallow and mid-depth plots in 2004 and at the deep plots in 2003 were used for this purpose. For the other areas, all data correspond to the evaluation in 2004.

In each area, temporal trends of coral and algae (pooled turf, fleshy, encrusting and calcareous) were evaluated by repeated measures ANOVA due to repeated sampling of the same transects. The model included the effect of depth levels (a fixed effect), monitoring plots (a random effect) as a nested factor within depths, and time (repeated factor). Considering the review and recommendations of Ende (1993) to apply repeated measures analysis, we used the univariate approach and the GreenhouseGeisser corrected probability to test F. The appropriate tests of significance of each term were also calculated using a variety of MS error terms obtained by means of the variance components of the mixed model (Milliken \& Johnson 1992, Potvin 1993). Since this model requires a perfectly balanced data set, we excluded those surveys (years) in which not all depth levels on each reef area were evaluated. Where significant changes in coral and algae were found, annual changes in cover were graphically examined, and trends of the most representative coral species and algal components were also analyzed using repeated measures ANOVA. Prior to analyses, covers estimated were arcsine transformed (Sokal \& Rolf 1995, Zar 1999).

\section{RESULTS}

General condition and spatial patterns: Overall means of coral and algal cover were $27.2 \%$ and $43.4 \%$ respectively, revealing algal dominance in most of the areas studied (Fig. 1). A similar coral vs. algae pattern was observed over the three depths as follow: $34.5 \%$ vs. $42.3 \%$ in shallow, $25.3 \%$ vs. $45.1 \%$ in middepth and $24.1 \%$ vs. $38.4 \%$ in deep plots (Fig. 2). This pattern is the result of higher cover of algae relative to coral in $75 \%$ of the monitoring plots (Table 1). Live coral cover at different monitoring plots ranged greatly from $5.4 \%$ at Santa Marta to $67.2 \%$ at Urabá, and algal cover from $23.2 \%$ at Urabá to $81.8 \%$ at San Andrés (Table 1). In general, these maxima and minima values were found in the shallow plots.

Overall means (Table 2) indicated that algal turf was the most abundant algal and biotic component in nearly all reef areas, ranging from $14.7 \%$ at Rosario up to $44.2 \%$ at Santa Marta. Nevertheless, at Urabá the hard coral Siderastrea siderea was the main biotic component with $30.7 \%$ cover (Table 2). Other components such as encrusting algae, fleshy algae and sponges showed noticeable covers of $13.7 \%$ (Tayrona), $12.8 \%$ (San Andrés) and $7.2 \%$ (Santa Marta). Coral species reaching up to $10 \%$ cover were Montastraea faveolata $(10.3 \%$ and $9.2 \%)$ in Tayrona and San Bernardo respectively, M. franksii $(7.1 \%)$ in 


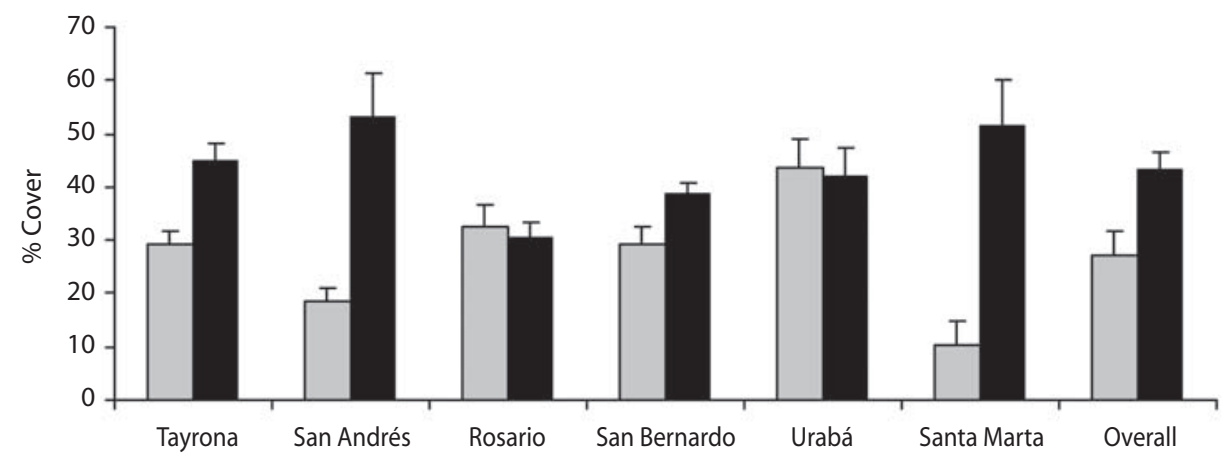

Fig. 1. Means (+1 SE) of live coral and algal cover at six Colombian Caribbean reef areas. Values were calculated with the latest monitoring data set (see data analysis for explanation).

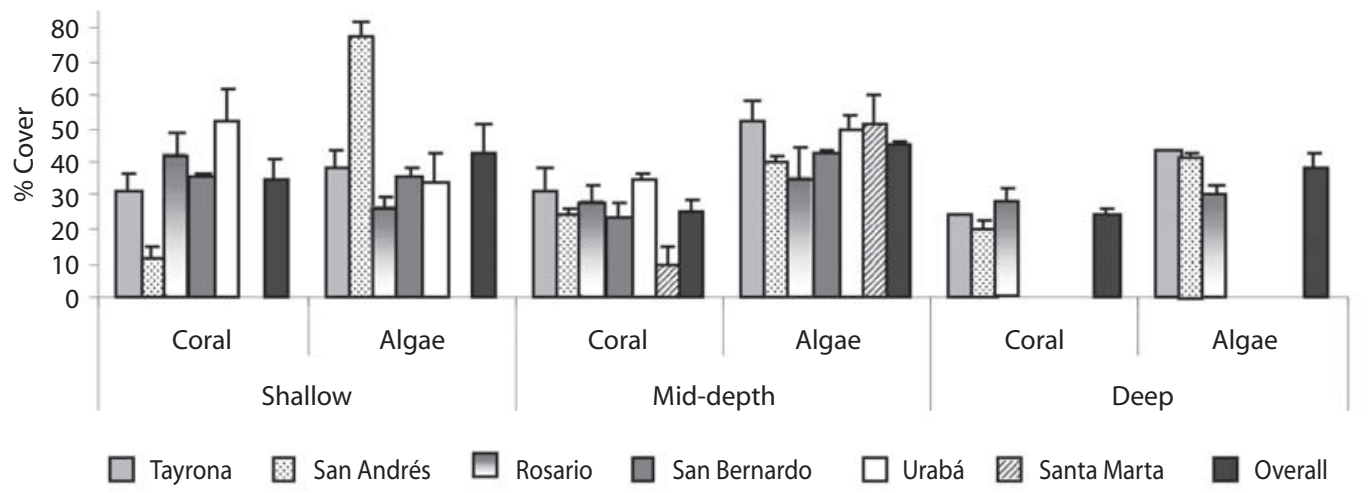

Fig. 2. Means (+1 SE) of live coral and algal cover at six Colombian Caribbean reef areas by depth level. Values were calculated with the latest monitoring data set (see data analysis for explanation).

San Andrés, Agaricia teunifolia (12.8\%) in Rosario, and Diploria strigosa (2.7\%) in Santa Marta (Table 2).

At the plot level, the highest percentages in coral components were observed for $S$. siderea in shallow plots at Urabá (65.4\%), M. faveolata in shallow plots at Tayrona and San Bernardo (13.3\% and $14.5 \%$ respectively), $M$. franksii in deep plots at San Andrés (8.9\%), and A. teunifolia $24.6 \%$ in the mid-depth plots at Rosario (Table 2). Cover percentages for all biotic components by plot are showed in Table 2 .
Recent dynamics: Repeated measures ANOVA showed that there were no significant changes in coral cover from 1998 to 2004 for most of the areas (Table 1). The only significant temporal change in coral cover depended on the monitoring plots at Tayrona -significant time $\mathrm{x}$ plot (depth level) interaction, $\mathrm{p}=0.04$. Coral cover differentially varied among some monitoring plots (Fig. 3A, B, C), decreasing in one of the shallow plots (Chengue 2) and also in both of the deep plots. Total rates of coral loss ranged from $-6.0 \%$ to $-11.1 \%$ (Fig. 3D, 


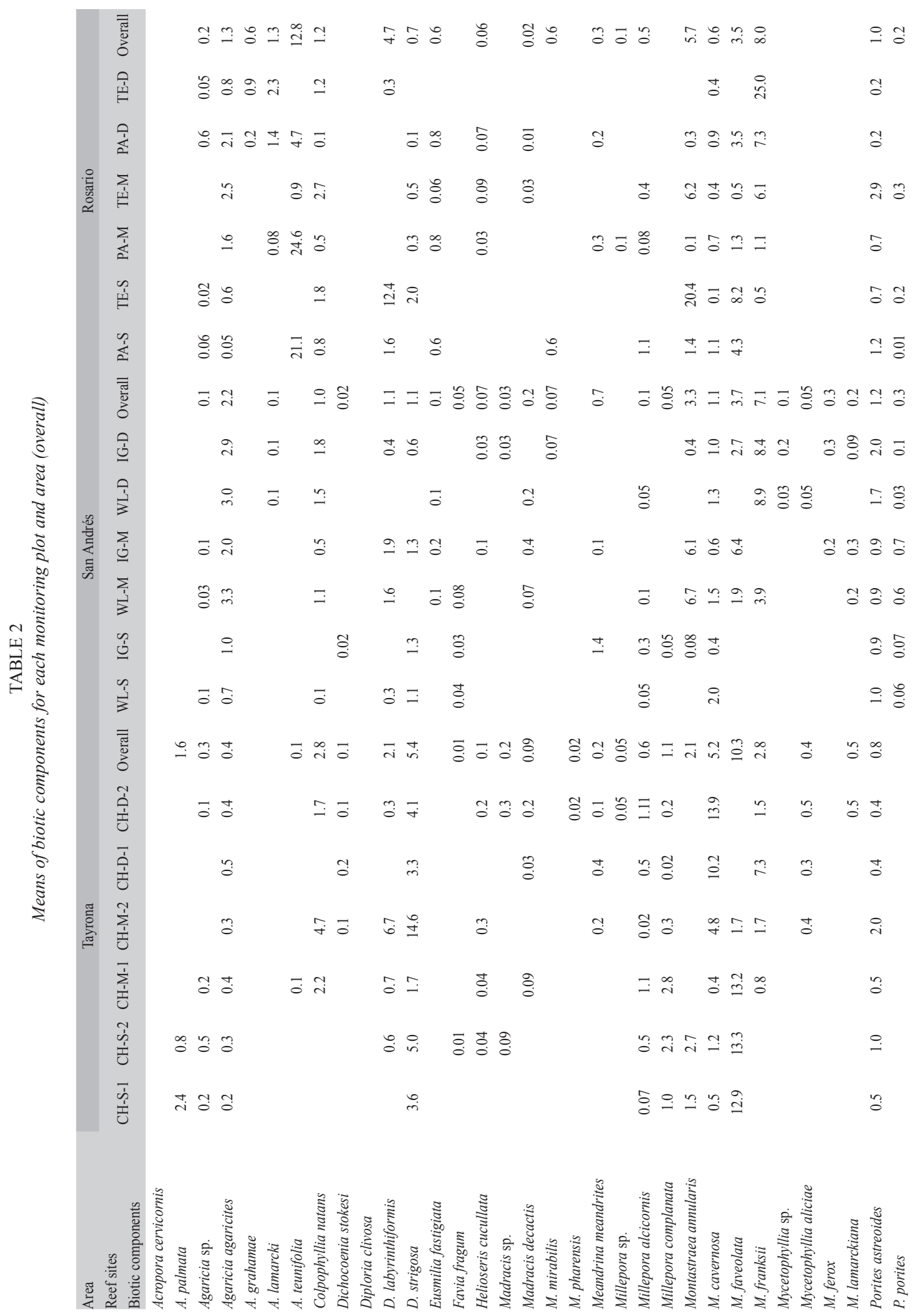




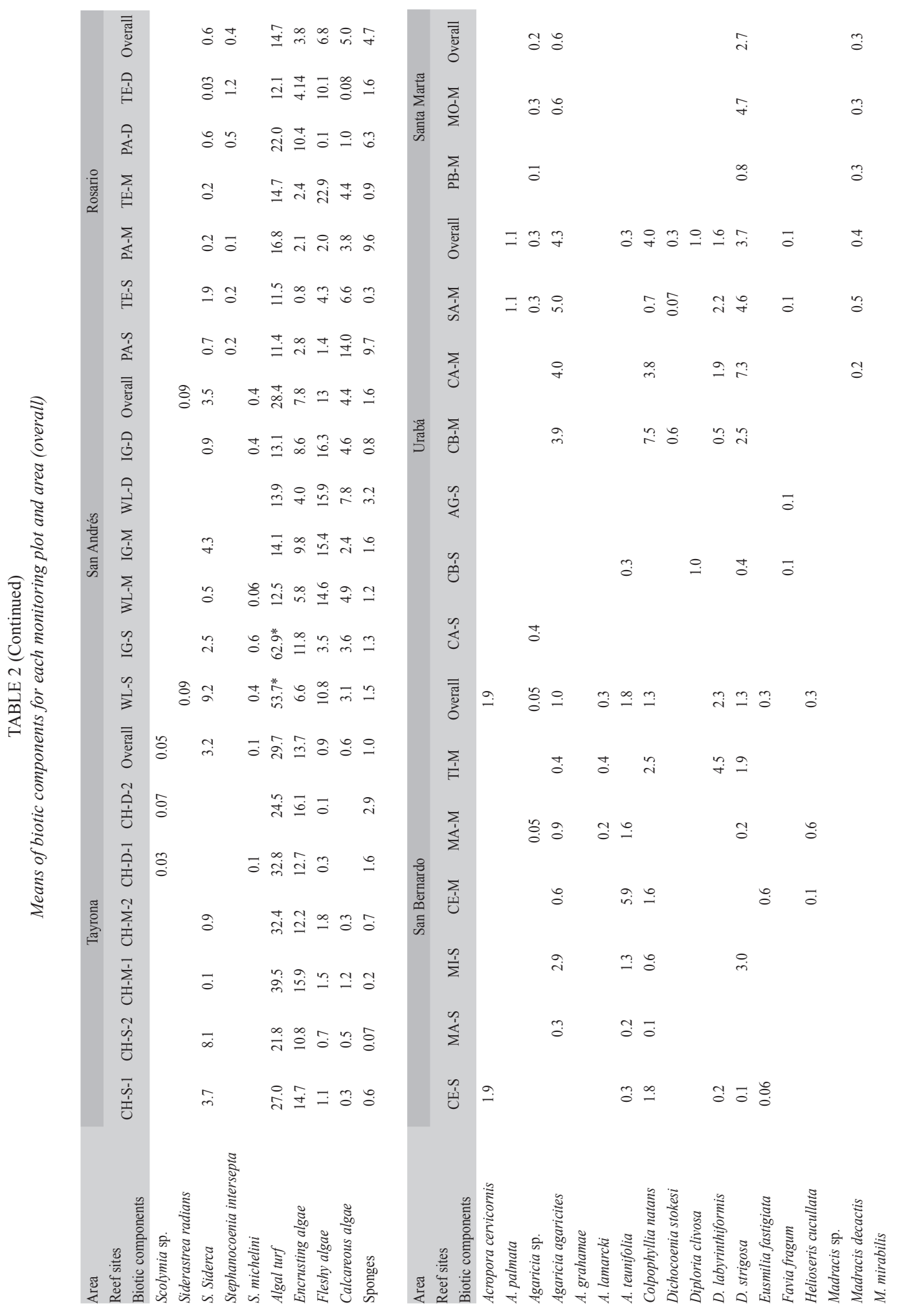




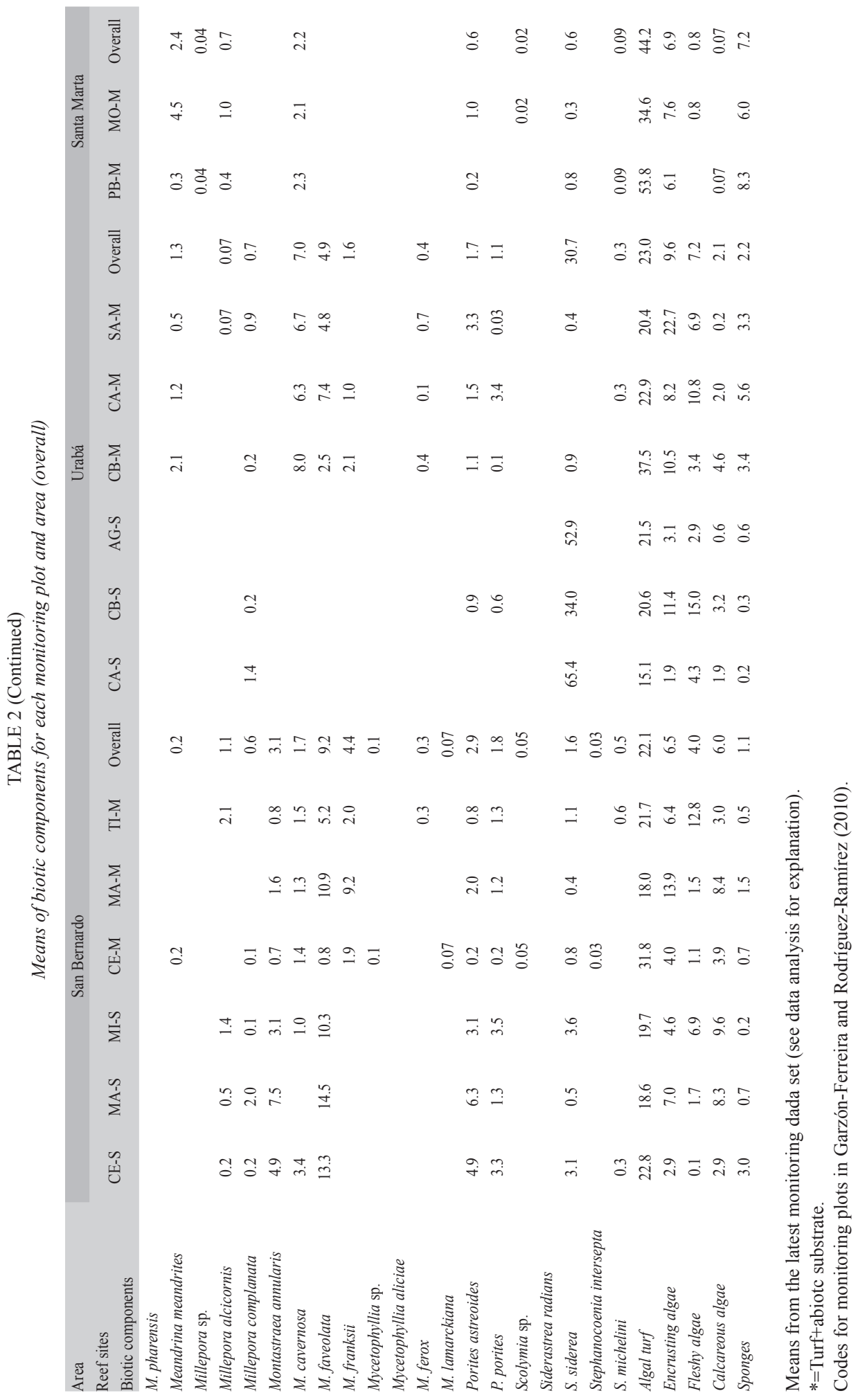



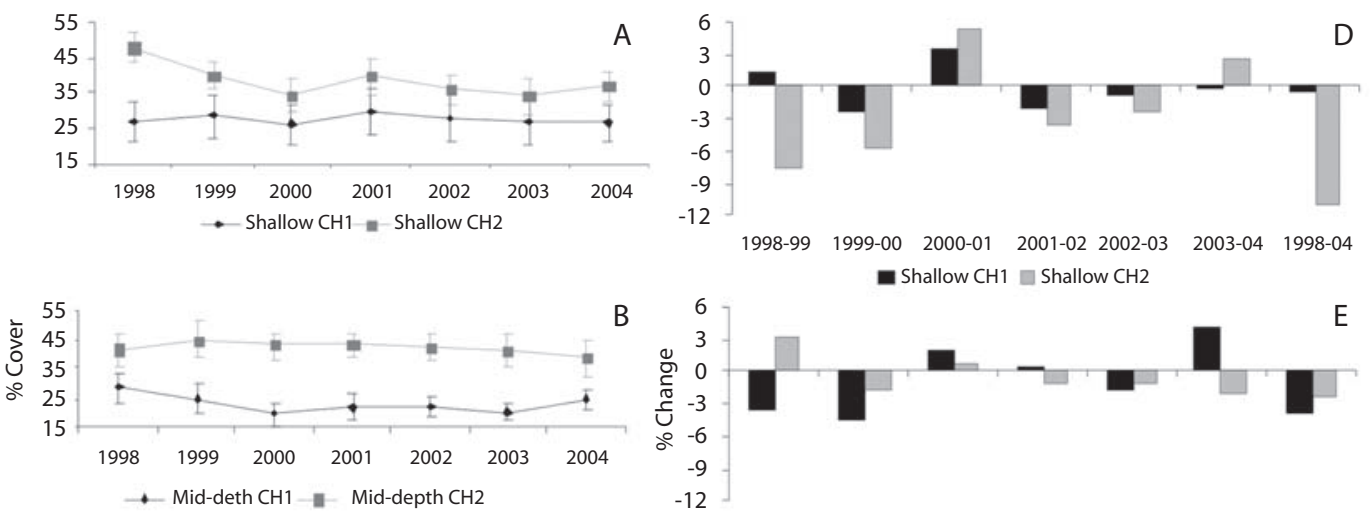

- Shallow $\mathrm{CH} 1$ Shallow $\mathrm{CH} 2$
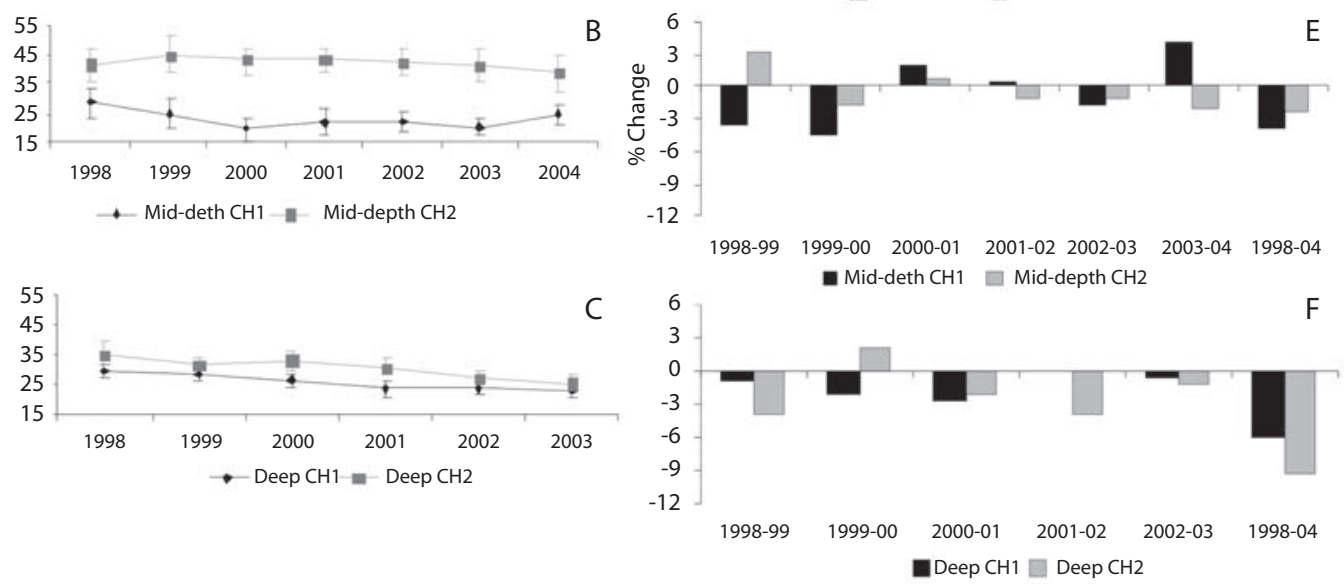

Fig. 3. (A, B, C) Variations in mean percentage coral cover ( \pm 1 SE) over period studied for each plot at Tayrona. (D, E, F) Annual and total percentage change in coral cover by plot at Tayrona. $\mathrm{CH} 1=$ Chengue $1 ; \mathrm{CH} 2=\mathrm{Chengue} 2$.

3F). None of the mid-depth plots or the other shallow plot (Chengue 1) showed patterns of change in coral cover. While positive and negative variations in coral cover were identified for these plots, the total percentages of change were less than $-4 \%$ (Fig. 3D, 3E).

For monitoring plots where there were significant declines in coral cover, the changes in coral species did not necessarily follow the overall trend (Fig. 4). Although several variations were observed (increases or decreases), only $S$. siderea and Acropora palmata at shallow plot of Chengue 2 (Fig. 4A), and Montastraea cavernosa at both deep plots (Fig. 4B, 4C) significantly decreased ( $\mathrm{p}=0.014$, $\mathrm{p}=0.010, \mathrm{p}=0.019, \mathrm{p}=0.009$ respectively). Total percentages of change were $-3.2 \%$ (S. siderea), $-4.4 \%$ (A. palmata), $-6.1 \%$ and $-8.0 \%$ (M. cavernosa).

Repeated measures ANOVA displayed significant changes in algal cover at Rosario, San Andrés, and Urabá (Table 1). At Rosario, there was a significant time effect $(\mathrm{p}=0.005)$ explained by increases in algal cover for most of monitoring plots during the studied period (Table 1; Fig. 5A, B, C). The percentage of algal cover increased 5.4\% from 1998 to 2003, being from 1999 to 2001 the years of major increase (Fig. 5D). Repeated measures ANOVA identified significant trends for these algal components: encrusting algae $(p=0.023)$ and algal turf $(\mathrm{p}<0.001)$ increased while fleshy algae $(p<0.001)$ decreased (Fig. 6). The total percentages of change for the algal components were $7.5 \%$ (turfs), $2.3 \%$ (encrusting) and $-5.2 \%$ (fleshy). There was no significant change in the abundance of calcareous algae (Fig. 6).

At San Andrés, temporal differences in the algal cover depended on the depth (significant time $\mathrm{x}$ depth interaction, $\mathrm{p}=0.004$, Table 1). Both plots at each depth showed a similar trend (Fig. 7A, B, C). Variations in the annual percentages of change resulted in a slight decrease at shallow plots $(-2.3 \%)$, but important increases 

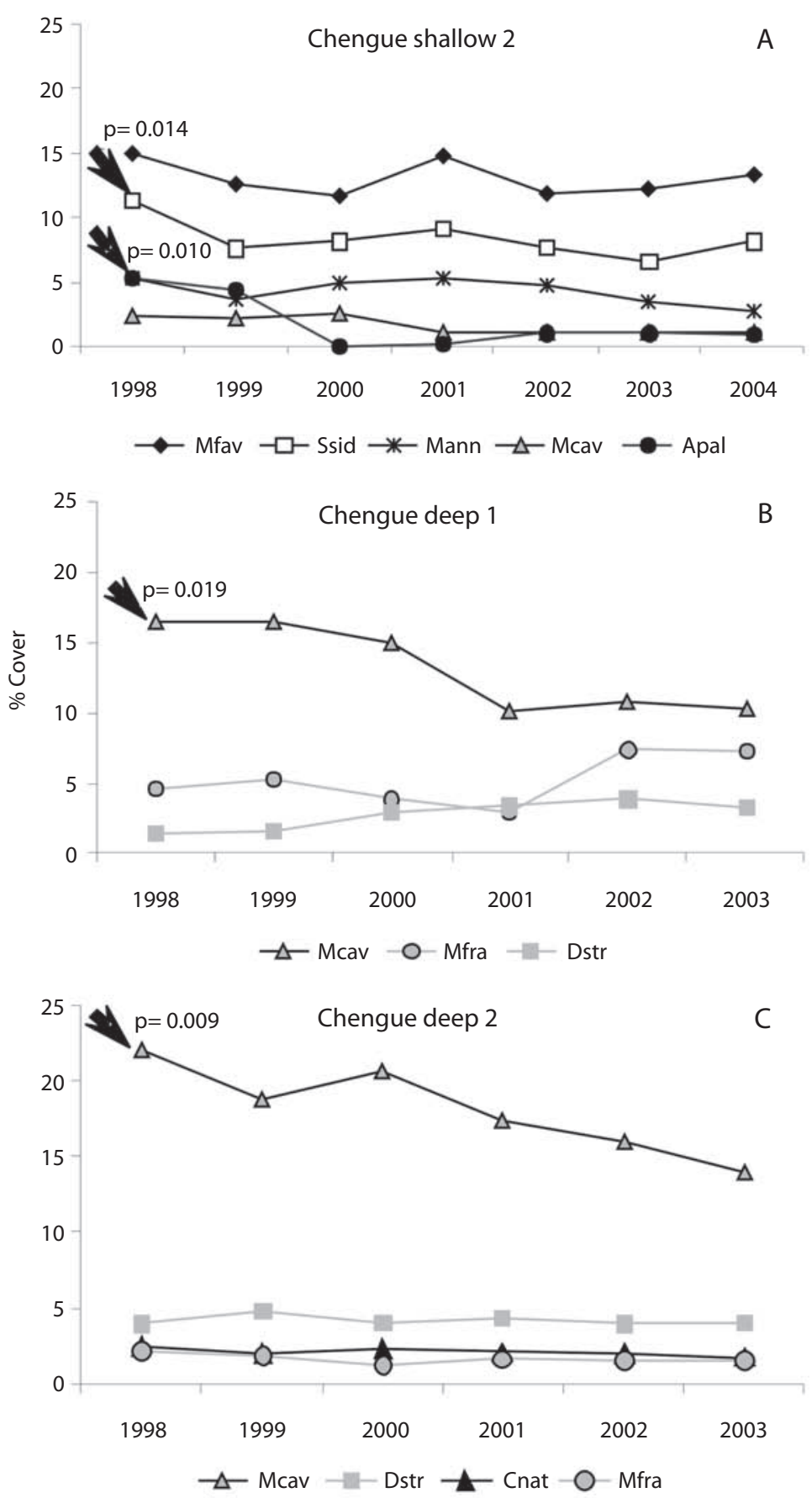

Fig. 4. Variations in mean percentage cover over period studied for the most representative coral species at (A) Chengue shallow 1, (B) Chengue deep 1, and (C) Chengue deep 2. These plots showed significant declines in coral cover at Tayrona. Arrows and p-values show coral species where repeated measures ANOVA analysis indicated significant trend. Apal= Acropora palmata $;$ Cnat $=$ Colpophyllia natans $; \mathrm{Dstr}=$ Diploria strigosa $;$ Mann= Montastraea annularis $;$ Mcav $=$ M. carvernosa $; \mathrm{Mfav}=$ M. faveolata $; \mathrm{Mfra}=$. . franksi; $\mathrm{Ssid}=$ Siderastrea siderea. Annual means were calculated with data set for each plot $(\mathrm{n}=5)$. 

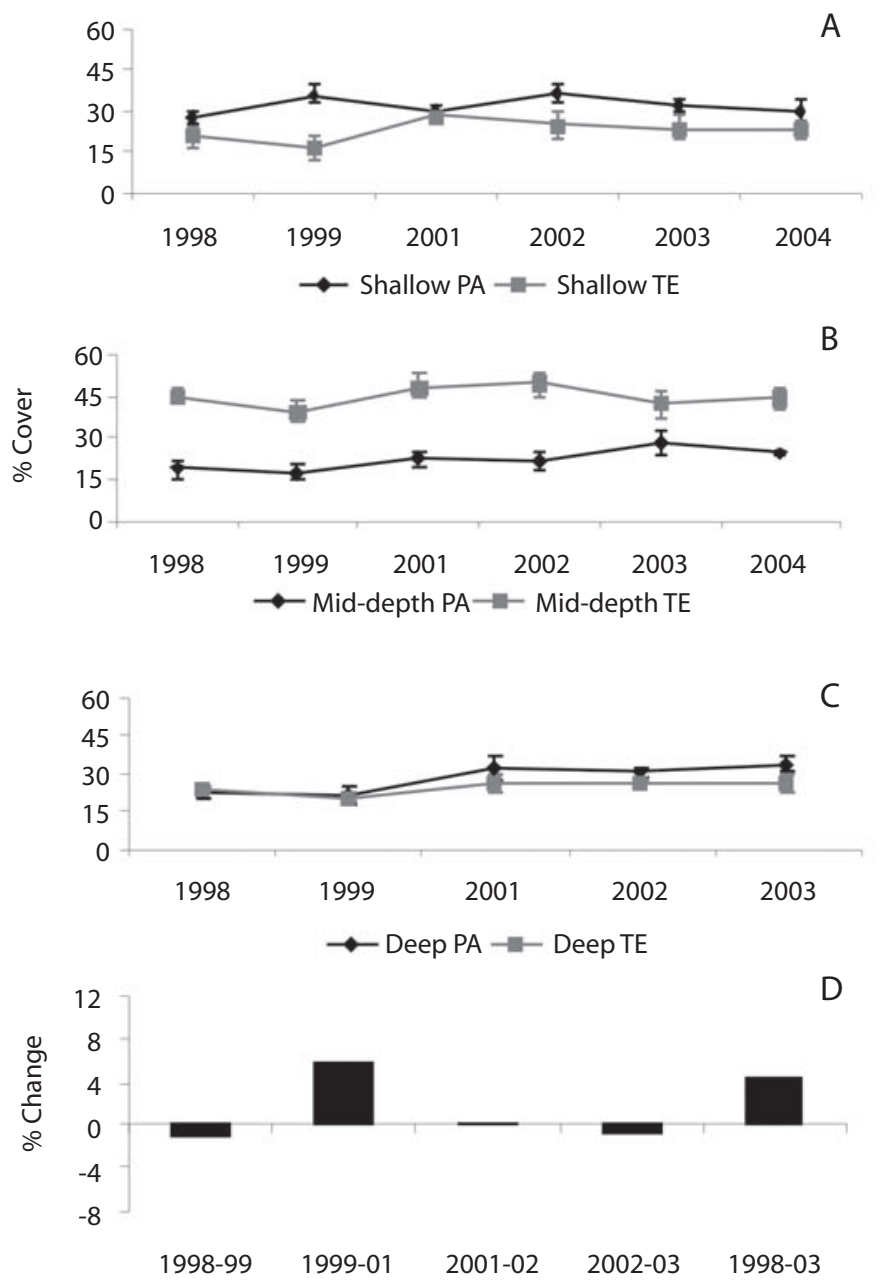

Fig. 5. (A, B, C) Variations in mean percentage algal cover ( \pm 1 SE) over period studied for each plot at Rosario. (D) Annual and total percentage change in algal cover at Rosario. $\mathrm{PA}=$ Pavitos; $\mathrm{TE}=$ Tesoro.

at mid-depth and deep plots $(8.1 \%$ and $8.3 \%$ respectively; Fig. 7D, 7E). Repeated measures ANOVA indicated significant changes in cover of several algal components by depth levels. Significant increase for encrusting, fleshy and calcareous algae at shallow level (Fig. 8A; all $\mathrm{p}<0.001)$ and for turfs and encrusting at both mid-depth and deep levels (Fig. 8B, 8C; all $\mathrm{p}<0.05$ ) were detected. In contrast, turfs and calcareous significantly decreased at shallow and mid-depth plots respectively (Fig. 8A, 8B; $\mathrm{p}<0.001$ and $\mathrm{p}=0.011$ respectively). The total percentages of change were as follows: for turfs $-15.1 \%$ (shallow), 3.8\% (mid-depth) and $9.1 \%$ (deep), for encrusting $8.3 \%$ (shallow), $6.5 \%$ (mid-depth) and $4.8 \%$ (deep), for fleshy $1.6 \%$ (shallow), and for calcareous $2.9 \%$ (shallow) and $-3.0 \%$ (mid-depth).

In Urabá, temporal changes in algal cover were also influenced by the depth-significant time $\mathrm{x}$ depth interaction, $\mathrm{p}=0.027$ - (Table 1 ). Thus, the algae trajectory in the shallow plots decreased along the evaluated time, but was quite stable in the mid-depth plots (Fig. 9A, 


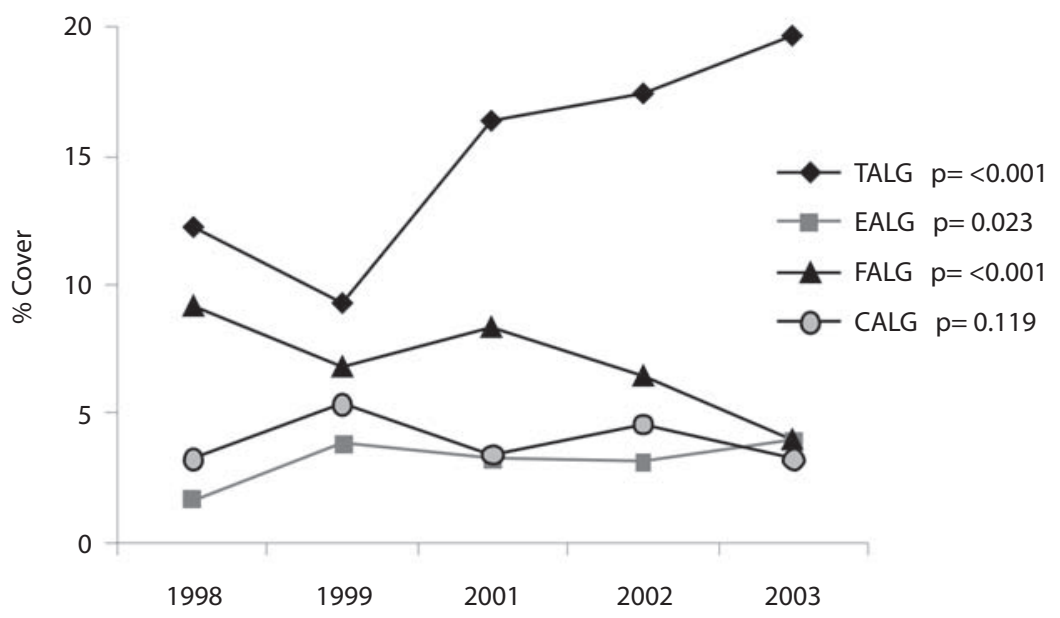

Fig. 6. Variations in mean percentage cover over period studied for algal components at Rosario. Results (p-values) of repeated measures ANOVAs are given for each algal component. TALG= Algal turf; EALG=encrusting algae; FALG= Fleshy algae; $\mathrm{CALG}=$ Calcareous algae. Annual means were calculated with data set for each year $(\mathrm{n}=30)$.
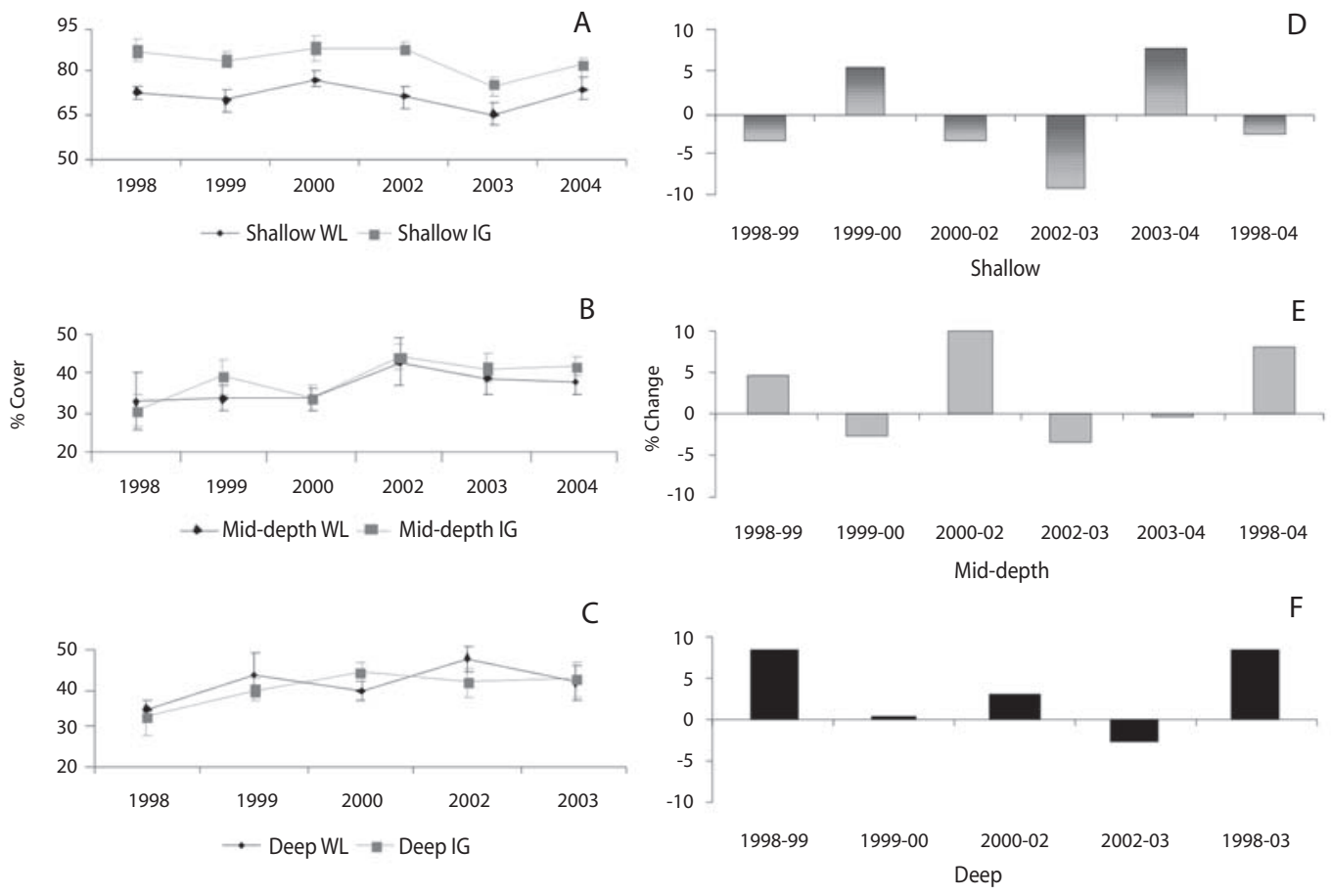

Fig. 7. (A, B , C) Variations in mean percentage algal cover ( $\pm 1 \mathrm{SE})$ over period studied for each plot at San Andrés. (D, E, F) Annual and total percentage change in algal cover by depth level at San Andrés. WL= Wild life; IG= Iguana. 

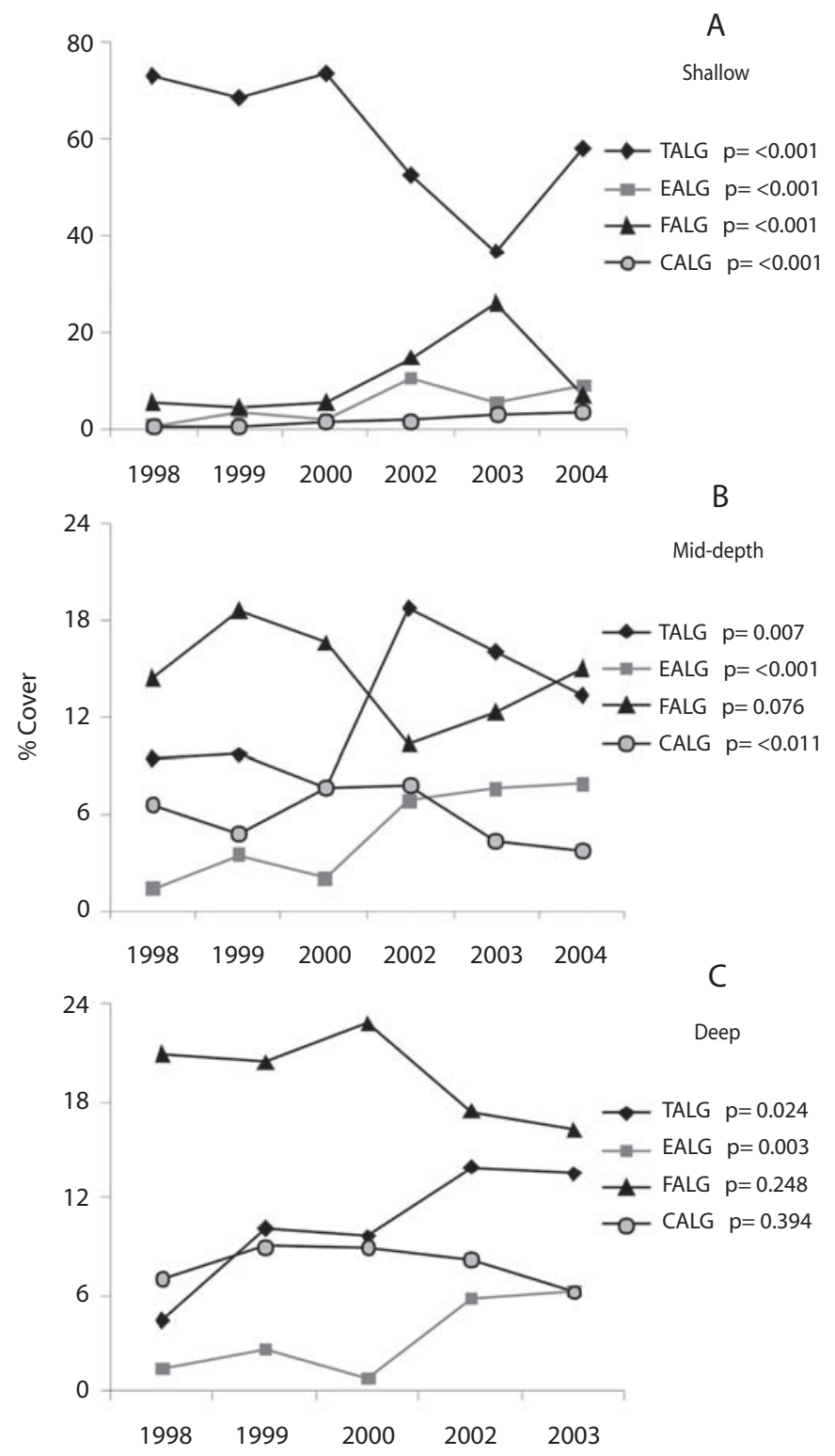

Fig. 8. (A, B, C) Variations in mean percentage cover over period studied for algal components by depth level at San Andrés. Results (p-values) of repeated measures ANOVAs are given for each algal component. TALG= Algal turf; EALG= Encrusting algae $; \mathrm{FALG}=$ Fleshy algae $\mathrm{CALG}=\mathrm{Calcareous}$ algae. Annual means were calculated with data set for each depth $(n=10)$.

9B). The annual percentages of algae change in the shallow plots were in the order of $-5 \%$, accumulating a total of $-9.3 \%$, while percentages of change were negligible in the mid-depth plots (Fig. 9C). Although most of algal components tended to decrease over the study period at shallow level, repeated measures ANOVA indicated significant decrease trend only for algal turf and calcareous algae (Fig. 10, $\mathrm{p}=0.044$ and $\mathrm{p}=0.042$ respectively). The total percentages 


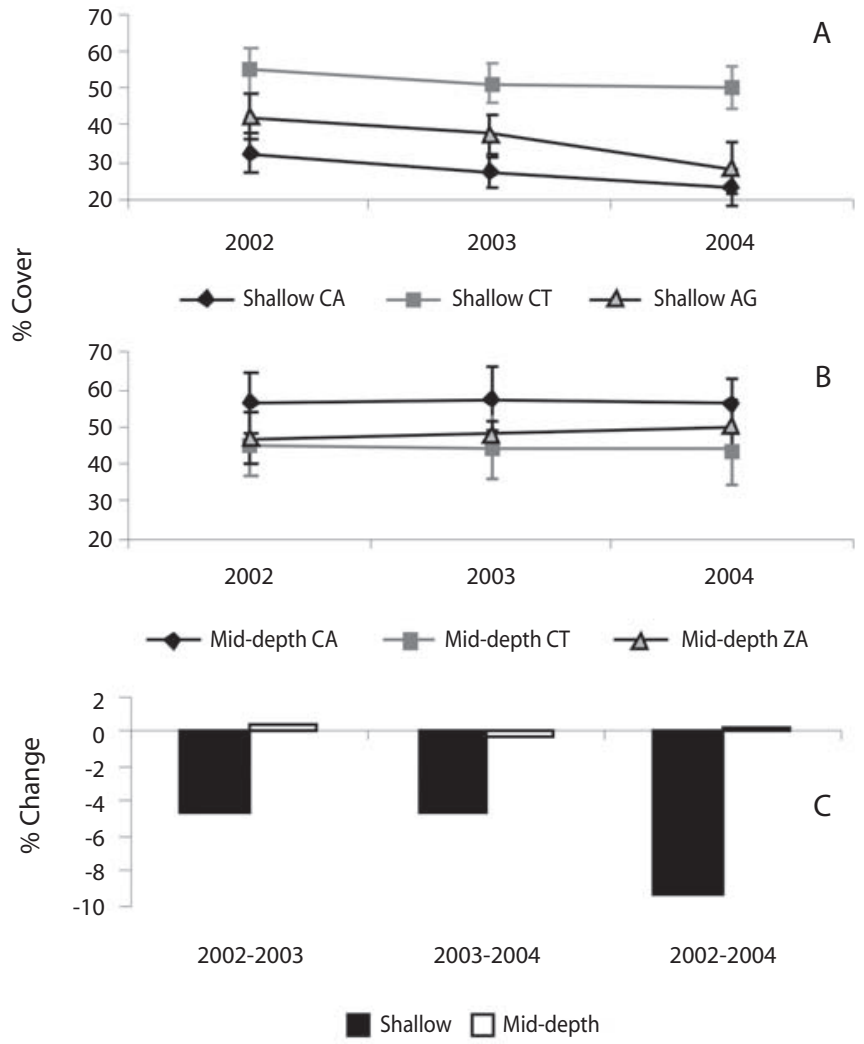

Fig. 9. (A, B) Variations in mean percentage algal cover ( $\pm 1 \mathrm{SE})$ over period studied for each plot at Urabá. (C) Annual and total percentage change in algal cover by depth level at Urabá. $\mathrm{CA}=$ Capurganá; $\mathrm{CT}=\mathrm{Cabo}$ Tiburón; $\mathrm{AG}=\mathrm{Aguacate} ; \mathrm{ZA}=$ Sapzurro.

of change for the two components were $-5.0 \%$ (turfs) and $-2.1 \%$ (calcareous).

\section{DISCUSSION}

General condition and spatial patterns: Overall, the monitoring plots exhibited a wide range of coral $(5.4 \%-67.2 \%)$ and algal cover $(23.2 \%-81.8 \%)$. Because of this high variability, general spatial patterns are difficult to identify. Several local studies have also identified high spatial variability not only within the main coral reef areas of Colombia (López-Victoria \& Díaz 2000, Díaz et al. 2000a, Cendales et al. 2002, Friedlander et al. 2003, Sánchez et al. 2005) but also when compared (Díaz et al. 2000b, Diaz-Pulido et al. 2004). Evaluations on regional scale such as CARICOMP and AGRRA also reveal similar results. For instance, algal cover can range from less than $5 \%$ in Cayo Sombrero, Venezuela up to $90 \%$ in Puerto Morelos, México (CARICOMP et al. 2002, Linton \& Fisher 2004) and coral cover can vary from $2.5 \%$ in Costa Rica to $57.8 \%$ in Flower Garden Banks, USA (Kramer 2003).

Despite the high variability in the algal component, two general spatial patterns were identified: 1) algae were predominant over the other living organisms (including corals) and substrate categories and, 2) algal turfs were the most abundant algal component (turf $>$ encrusting $>$ fleshy $>$ calcareous). The scenarios 


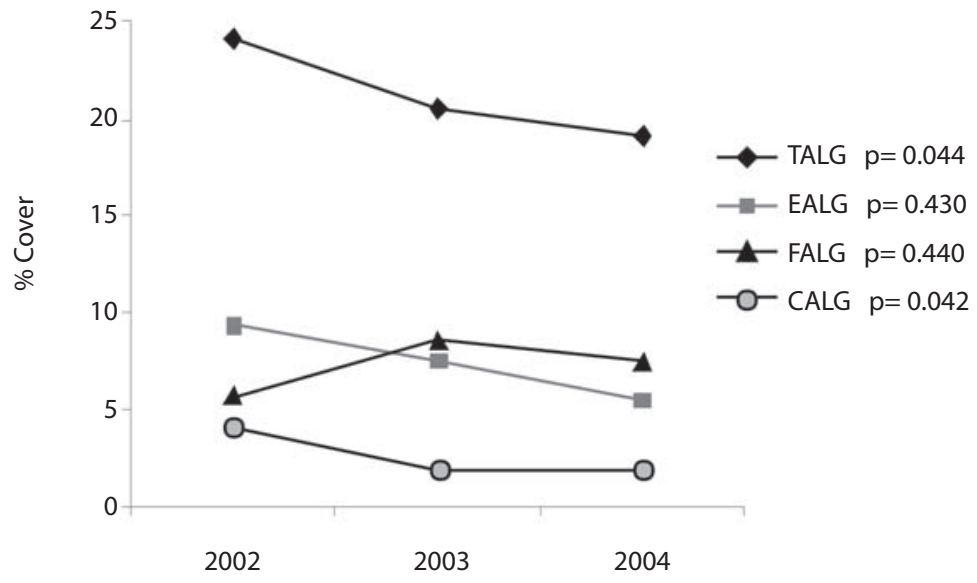

Fig. 10. Variations in mean percentage cover over period studied for algal components at mid-depth level of Urabá. Results ( $\mathrm{p}$-values) of repeated measures ANOVAs are given for each algal component. TALG=Algal turf; EALG= Encrusting algae; $\mathrm{FALG}=$ Fleshy algae; $\mathrm{CALG}=$ Calcareous algae. Annual means were calculated with mid-depth data set $(\mathrm{n}=9)$.

recognized here are consistent with those previously documented for the Caribbean and Western Atlantic (Liddell \& Ohlhorst 1993, Hallock et al. 1993, Ginsburg 1994, Hughes 1994, Shulman \& Robertson 1996, McClanahan \& Muthiga 1998, Aronson \& Precht 2000, Edmunds \& Carpenter 2001, CARICOMP et al. 2002, Kramer 2003, Diaz-Pulido et al. 2004). This generalized condition appears to be the result of decline processes experienced by coral reefs during the past decades and is mainly associated with a combination of natural and antropogenic factors (Done 1992, Hallock et al. 1993, Hughes 1994, Hughes \& Connel 1999, Nyström et al. 2000, Szmant 2002, Gardner et al. 2003, Pandolfi et al. 2003, Burke \& Maidens 2004, Buddemeier et al. 2004). High algae abundance, particularly algal turfs, must however be interpreted as a consequence but not as a cause of coral mortality (McCook et al. 2001, Diaz-Pulido \& McCook 2002).

Hard corals displayed two main spatial patterns related to their abundance and composition: 1) percentage cover of individual species rarely exceeded $10 \%$ and, 2) total living coral was accounted by few species. Montastraea spp. were the most represented hard corals for many of the monitored plots at Tayrona, San
Bernardo and San Andrés, while A. teunifolia was the most abundant species at Rosario. Similarly, the predominance of these species has been observed across the Colombian Caribbean (Diaz-Pulido et al. 2004) and also in the Wider Caribbean (Kramer 2003, Rogers \& Miller 2006). In contrast, high cover of the reef-building coral $S$. siderea was measured in Urabá. This species predominates in the shallow fringing reefs (up to $67.2 \%$ ), comprising around $97 \%$ of the total living coral. Since other coral reef assemblages at Urabá have shown unequivocal signs of decline, for example extensive debris field of Acropora cervicornis and dead colonies of Agaricia spp. overgrown by algae (Díaz et al. 2000a), the high abundance of $S$. siderea could have importance in terms of coral reef resistance and resilience. This species appears to be more tolerant than other coral species experiencing similar perturbations in the area.

Our results allowed insights on the limitations of the coral and algae values as reef health indicators. While we identified that coral cover varied over scales from meters to kilometers, we emphasize that this characteristic is not only associated with degradation as variability may also naturally occurs. San Andrés is a clear example where coral cover varies 
from $7.3 \%$ to $26.0 \%$ over a meter scale (30$100 \mathrm{~m}$ ) as a result of both the natural variation and degradation. Although general declines in coral cover have been identified for this area (Díaz et al. 1995, 2000b, Zea et al. 1998), low mean coral cover corresponded to the shallow plots where this condition is typical-calcareous terraces with scattered encrusting or massive corals (Díaz et al. 2000b). Santa Marta and Tayrona reefs displayed differences in coral cover ranges (from $5.4 \%$ to $14.8 \%$ and from $23.2 \%$ to $38.7 \%$ respectively) even though they are located few kilometres apart. Unlike San Andrés, the poor coral cover in Santa Marta is explained by a well-documented decline process mainly associated with unmanaged coastal development in the area (Zea 1993 \& 1994, Acosta 1994, Díaz et al. 2000b, GarzónFerreira \& Díaz 2003, Martínez \& Acosta, 2005). We also identified challenges with using coral or algal cover, independently for comparative purposes. Although plots can have similar coral cover, their algal cover can be different (see Ceycen shallow vs. Cabo Tiburón shallow and Tesoro deep vs. Capurganá mid-depth, Table 1). Disregarding algae cover for these cases could lead to inaccurate interpretations as coral cover alone is similar among these plots. Furthermore, simply comparing coral cover between areas without considering species composition overlooks meaningful ecological differences. For instance, the highest coral cover registered in this study was for a single species ( $S$. siderea) which is ecologically different than high coral cover comprising several species.

Different perspectives regarding the limitations of coral cover as indicators of reef health have been argued for more than ten years. Birkeland (1997) pointed out that low coral cover may occur in a "healthy" community, depending on the particular circumstances. Hughes \& Connell (1999) discussed the difficulties defining normal values for coral reef indicators since low coral cover could indicate the short-term impact of a recent natural disturbance or spatial variability in coral abundances. Hughes \& Tanner (2000) cautioned that coral increases may occur in a population despite its imminent decline (and vice-versa). According to Jackson (1997) there is no historical baseline data for the condition of coral reefs to support accurate conclusions about current coral reef health. Given that managers and stakeholders require information to implement appropriate conservation strategies, the lack of information is problematic. Thus, covers of coral or algae alone are not sufficient to determine reef condition and this illustrates the constraints associated with their use as status indicators. Determining a consensus on benchmarks that establish the status of coral reefs through an examination of both historic and current data is necessary.

The Caribbean coral reefs in Colombia cover more than $2800 \mathrm{~km}^{2}$ and are scattered among 24 areas that display a high diversity of habitat types (Díaz et al. 2000b). Based on these characteristics and the plots here assessed, our outcomes represent the first attempt to quantitatively identify the coral reef status on several areas after declines in the 1980's and 1990's. The values for algae and coral cover need to be interpreted cautiously and combined with additional information such as reef type, depth, biotic components, historical context, and local environmental conditions.

Recent dynamics: The results of this study are meaningful because they document reef trends in the Southern Caribbean after decades of coral reef degradation. In this region coral and algal dynamics have been poorly documented at any temporal scale. Our findings did not show overall pattern of decrease in coral cover or increase in algae cover for six monitored reef areas but did suggest a stability of coral reefs from 1998 to 2004. This appears to conflict with two meta-analyses pointing out significant trends of decline in the Caribbean, in particular the loss of coral cover and/ or increase in algae abundance (Gardner et al. 2003, Côté et al. 2005). Our results neither reject nor support such trend because they are slightly outside the scope of these meta-analyses (1977-2001). The most dramatic changes across the Caribbean (including Colombia) 
were observed in the late 1970's, through the 1980's and into the early 1990's when multiple natural and human stressors interacted broadly (Dustan \& Halas 1987, Hughes 1989, 1994 and 1996, Porter \& Meier 1992, Liddell \& Olhorst 1993, Garzón-Ferreira \& Kielman 1994, Shulman \& Robertson 1996, McClanahan \& Muthiga, 1998, Hughes \& Tanner 2000, Jackson et al. 2001, Pandolfi et al. 2003). No major disturbances have been recorded at the Colombian Caribbean reefs from 1998 to 2004 (Garzón-Fereira et al. 2004, RodríguezRamírez et al. 2006), which could lead to a short-term stability in coral and algal cover. Recent studies on coral reef dynamics elsewhere in the Caribbean and Florida Keys have shown a similar pattern of stability in coral cover during the period from 1999 to 2003 (Rogers \& Miller 2006, Edmunds \& Elahi, 2007, Somerfield et al. 2008). However, the lack of coral cover decrease in the monitored plots does not imply that other Colombian reefs have not been experiencing declines. It has been documented that losses in coral cover have occurred on continental and oceanic reefs of Colombia (i.e. Martínez \& Acosta 2005, see Sánchez et al. 2010).

The general trend of stability recognized here supports studies highlighting an overall lack of recovery in coral cover throughout the Caribbean (Connell 1997, Gardner et al. 2005, Rogers \& Miller 2006, Edmunds \& Elahi, 2007, Somerfield et al. 2008). Our outcomes suggest negligible contributions to coral recovery through adult colony growth. Exceptional cases have recorded significant increases in coral cover attributed to growth of pre-existing colonies across the Caribbean (Bythell et al. 2000, CARICOMP et al. 2002, Rogers \& Miller 2006). Because the growth rate for most representative species in the monitoring plots is only a few millimetres per year (e.g. Montastraea complex) (Hubbard \& Scaturo 1985), longer monitoring timescales may be required to detect significant changes in coral cover. Recovery processes linked to recruitment require further investigation as the SIMAC program does not assess the abundance of recruits and only few studies in Colombia have focused on this subject (Vidal et al. 2005, Acosta et al. 2006, López-Londoño et al. 2007, Pizarro et al. 2007). While corals are currently recruiting in many places across the Caribbean (Cho \& Woodley 2002, Kramer et al. 2003, Carpenter \& Edmunds 2006), recruitment failure and demographic models indicate that coral populations cannot be restored by recruitment (Hughes 1996, Hughes \& Tanner 2000, Edmunds \& Elahi 2007). Thus, monitoring programs must evaluate the role of recruitment on local spatial scales in order to provide insights on coral reef dynamics and long-term recovery trends.

The only significant change in coral cover was detected at Tayrona, and importantly, few species explained the trend. S. siderea and $A$. palmata at a shallow plot (Chengue 2), and $M$. cavernosa at two deep plots registered significant decreases. Reductions in A. palmata were associated with impacts from hurricane Lenny in 1999. This hurricane did not strike Colombia but caused unusually strong waves along the coast and damage on coral reefs at Tayrona (Rodríguez-Ramírez \& Garzón-Ferreira 2003). Shortly after the disturbance, we observed injuries to massive corals whereas branching corals, mostly A. palmata, were overturned and/or shattered. For this species, there was no sign of recovery post 1999 in follow-up assessments (Fig. 4A). In contrast, the reasons for the decline of $M$. cavernosa and $S$. siderea remain unclear. While the continuous reductions for M. cavernosa (Fig. 4B, 4C) may reflect the effects of chronic mortality, low prevalence of coral diseases have been recorded at these plots (Navas et al. 2010), suggesting alternative mechanisms. A major decrease in $S$. siderea cover between 1998 and 1999 (Fig. 4A) appeared to be associated with a period of bleaching events at Tayrona. Nonetheless, studies documented that those events had little effect on coral mortality (Rodríguez-Ramírez \& Garzón-Ferreira 2003, Rodríguez-Ramírez et al. 2008b). Several studies have documented that individual reefs or coral species may follow variable trajectories depending on local 
disturbances or conditions (Hughes 1989, Shulman \& Robertson 1996, Connell et al.1997, Bythell et al. 2000, Edmunds 2002, Rogers \& Miller 2006, Somerfield et al. 2008). Our findings indicated that the recent declines in coral cover occurred locally on some species suggesting differential responses of corals to the same stressors. Results from this study document the importance of evaluating temporal changes at lower levels of resolution because trends in overall coral cover may mask variations within lower taxonomic units.

As expected, algae were the most dynamic component evaluated and two major aspects were documented. First, temporal patterns in algal cover displayed considerable variability among and within areas. Although algal cover remained stable over the monitoring period for some areas (Tayrona, San Bernardo and Santa Marta), significant trends were identified for Rosario (significant time effect with generalized increase), San Andrés (changes influenced by the depth, decrease at shallow plots and increases at mid-depth and deep plots) and Urabá (changes influenced by the depth, decrease at shallow plots). This variability demonstrates that algae responded differentially after coral cover declines and they did not necessarily increase in recent years. Similarly, no distinct trends in algal cover have been evident across the Caribbean (CARICOMP et al. 2002). Second, areas where there were significant changes in algal cover, only some algal components explained the overall trend. In general algal turf accounted for more variation in algal changes than any other functional group. This provides further evidence to support the recommendation to evaluate temporal dynamics at low taxonomic levels (coral species or algal functional groups) since trends among similar benthic organisms may be not uniform. Some studies have found that patterns of change in cover of algal components such as macroalgae and turf may differ (Edmunds 2002, Rogers \& Miller 2006).

Differential trajectories of algae and their components in each area suggest that they could be locally affected by biotic and environmental factors and their interactions. Abundance of herbivorous fish and sea urchins (unpublished data) could not be used to explain algal trends because these data sets are shorter (2002-2004) than reef benthic information. Very few studies in Colombia have related algal abundance with biological and environmental variables (DiazPulido \& Díaz 1997, Diaz-Pulido et al. 2004). In general, the abundance of benthic algae was attributed to coral mortality in concert with low levels of herbivory (Diaz-Pulido et al. 2004). Relations between temporal variations in algal cover and environmental factors are even scarcer for Colombia. Seasonal changes in algal abundance on continental reefs were associated with seawater temperature (Diaz-Pulido \& Garzón-Ferreira 2002). Consequently, it is critical to investigate the processes regulating algal abundance in monitoring reefs in order to explain the trends and, most importantly their role in reef dynamics. Since algal turfs are the most abundant and dynamic benthic component on monitored reefs, we suggest monitoring efforts to determine the processes mediating their abundance and effects on corals. While there is some evidence of competitive superiority of corals over algal turfs (McCook 2001, Jompa \& McCook 2003a, 2003b), the general consensus is that algae (including algal turfs) may prevent coral recruitment and recovery (Birkeland 1977, Hughes 1989, 1994, McCook et al. 2001, Diaz-Pulido \& McCook 2002, Birrell et al. 2005, Rogers \& Miller 2006, Box \& Mumby 2007).

In summary, our findings expand the knowledge about the status and recent dynamics on six coral reefs areas in Colombia, subsequent to reef decline that occurred across the Caribbean. These findings are essential to develop guidelines for reef biodiversity management in Colombia, complement the data on the long-term coral reef dynamics in the Caribbean, and serve as a "baseline" for future studies. Monitored sites in Colombia resemble many reefs across the Caribbean where algae are the most abundant biotic component. We draw attention on the limitations of using coral or algae cover per se as reef indicators of reef 
health because these values alone may lead to erroneous interpretations on the reef condition. Supplementary information such as reef type, depth, and biotic components in an historical context is required in order to have a more realistic picture of reef status. Recent dynamics in the studied reefs were characterized by: 1) a slowing of coral reef decline in recent years -no general trends of coral decrease or algal increase, 2) an overall lack of coral recovery at monitored plots. Temporal analysis disclosed differential trajectories in coral and algal cover which were explained by few coral species and algal components. Hence, monitoring programs need to evaluate not only overall changes of coral or algae but also the trends of their components (coral species and algal functional groups). Because the causes of the observed trajectories were not often identified, reef monitoring should assess the mechanisms mediating the changes, in particular those concerning coral recovery and reef resilience in order to find key answers to face coral reefs decline in the current context of climate change.

\section{ACKNOWLEDGMENTS}

This work has been funded in great part by grants from COLCIENCIAS, Ministerio del Medio Ambiente, Vivienda y Desarrollo Territorial (MAVDT) and the Regional Coordinating Unit of the Caribbean Environment Programme of the United Nations Environment Programme (UNEP-CAR/RCU). The Instituto de Investigaciones Marinas y Costeras (INVEMAR) has provided most of the required logistics and indirect costs. Other institutions that have contributed substantially with funds and/or logistical support are: Corporación para el Desarrollo Sostenible del Archipiélago de San Andrés, Providencia y Santa Catalina (CORALINA); Centro de Investigación, Educación y Recreación (CEINER); Universidad del Valle; Universidad de Antioquia Sede Turbo; Universidad Nacional, Unidad Administrativa Especial del Sistema de Parques Nacionales Naturales de Colombia (UAESPNN); Caribbean Coastal Marine Productivity
(CARICOMP), and the Global Coral Reef Monitoring Network (GCRMN). Numerous colleagues and students from INVEMAR and other institutions have participated directly in the big task of monitoring Colombian reefs; without their assistance, this study would not have been possible. Contribution No. CTBR1043 from INVEMAR.

\section{RESUMEN}

Este trabajo contiene el primer análisis temporal de la información obtenida por el Sistema Nacional de Monitoreo de Arrecifes Coralinos en Colombia (SIMAC). Entre 1998 y el 2004 se monitorearon un total de 32 parcelas permanentes ubicadas a diferentes niveles de profundidad en seis áreas arrecifales del Caribe colombiano. Los patrones temporales de algas y corales fueron evaluados mediante análisis de varianza de medidas repetidas. Los promedios generales indicaron que las algas dominaron en la mayoría de las áreas evaluadas, variando de $30.3 \%$ (Rosario) hasta $53.3 \%$ (San Andrés). La cobertura coralina fluctuó considerablemente entre $10.1 \%$ (Santa Marta) y $43.5 \%$ (Urabá). Los arrecifes estudiados han permanecido relativamente estables durante el periodo evaluado en términos de algas y corales. El único cambio significativo en la cobertura se detectó en algunas parcelas de monitoreo del Tayrona, y pocas especies coralinas explicaron la tendencia de disminución. En Rosario se detectó una tendencia significativa de incremento para las algas en la mayoría de las parcelas. En San Andrés y Urabá las tendencias temporales (aumento y disminución respectivamente) se presentaron en ciertos niveles de profundidad. En estas dos áreas las tendencias en la cobertura de las algas fueron explicadas principalmente por cambios en los tapetes algales. En general las causas de los patrones observados no pudieron identificarse. Los programas de monitoreo deben evaluar no solo las tendencias generales de algas y corales sino también las de sus componentes (especies de coral y grupos funcionales de algas). Así mismo, deben enfocarse en evaluar los mecanismos involucrados en los cambios, en especial aquellos relacionados con la recuperación coralina y la resiliencia arrecifal, de manera que se pueda enfrentar el deterioro arrecifal en el actual contexto de cambio climático.

Palabras clave: Monitoreo, arrecifes de coral, condición, dinámica, SIMAC, Caribe colombiano.

\section{REFERENCES}

Acosta, A. 1994. Contamination gradient and its effect on the coral community structure in the Santa Marta area, Colombian Caribbean, p.233-239. In R.N. Ginsburg 
(ed.) Proceedings of the Colloquium on Global Aspect of Coral Reefs. Health, Hazards and History. RSMAS. University of Miami, Miami, USA.

Acosta, A., J. Camacho, M. Ruíz-García, D. Alvarez. 2006. Investigaciones desde la perspectiva de la conectividad, p.96-100. In INVEMAR (ed.) Informe del Estado de los Ambientes Marinos y Costeros en Colombia: Año 2005. INVEMAR, Santa Marta, Colombia.

Aronson, R.B. \& W.F. Precht. 1997. Stasis, biological disturbance, and community structure of a holocene coral reef. Paleobiology 23: 326-346.

Aronson, R.B. \& W.F. Precht. 2000. Herbivory and algal dynamics on the coral reef at Discovery Bay, Jamaica. Limnol. Oceangr. 45: 251-255.

Aronson, R.B. \& W.F. Precht. 2001. White-band disease and the changing face of Caribbean coral reefs. Hydrobiologia 460: 25-38.

Aronson, R.B., I.G. Macintyre, C.M. Wapnick \& M.W. O'Neill. 2004. Phase shifts, alternative states, and the unprecedented convergence of two reef systems. Ecology 85: 1876-1891.

Bak, R.P.M. \& G. Nieuwland. 1995. Long-term change in coral communities along depth gradients over leeward reefs in the Netherlands Antilles. Bull. Mar. Sci. 56: 609-619.

Bythell, J.C., M.Z. Hillis-Starr \& C.S. Rogers. 2000. Local variability but landscape stability in coral reef communities following repeated hurricane impacts. Mar. Ecol. Prog. Ser. 204: 93-100.

Birkeland, C. 1977. The importance of rate of biomass accumulation in early successional stages of benthic communities to the survival of coral recruits. Proc. 3rd Int. Coral Reef Symp. 1: 15-21.

Birkeland, C. 1997. Introduction, p.1-12. In C. Birkeland (ed.) Life and death of corals reefs. Chapman \& Hall, Nueva York, USA.

Birrell, C.L., L.J. McCook \& B.L. Willis. 2005. Effects of algal turfs and sediment on coral settlement. Mar. Pollut. Bull. 51: 408-414.

Box, S.J. \& P.J. Mumby. 2007. The effect of macroalgal competition on the growth and survival of juvenile Caribbean corals. Mar. Ecol. Prog. Ser. 342: 139149.

Buddemeier, R.W., J.A. Kleypas \& R.B. Aronson. 2004. Coral reefs \& global climate change. Potential contributions of climate change to stress on coral reef ecosystems. Pew Center on Global Climate Change, Arlington, USA.

Burke, L. \& J. Maidens. 2004. Reefs at risk in the Caribbean. World Resources Institute, Washington DC., USA.

CARICOMP. 2001. CARICOMP Methods manual, levels 1 and 2: Manual of methods for mapping and monitoring of physical and biological parameters in the coastal zone of the Caribbean. CARICOMP Data Management Center, University of the West Indies, Jamaica.

CARICOMP, G.F. Warner, S.R. Smith, E. Jordan-Dahlgren, D.M. Linton, J.D. Woodley, P. Alcolado, K. Bonair, D. Bone, K.C. Buchan, P. Bush, J. Cortés, A. Croquer, K. De Meyer, R.G. Fernández, A. Fonseca, J.R. García, P. García-Parrado, J. Garzón-Ferreira, P. Gayle, D.T. Gerace, F.X. Geraldes, J. Gunther, R. Guppy, R. Juman, K.H. Koltes, E. Knobbe, E. Klein, R. Laydoo, F. Losada, G. Menendez, J.M. Mow-Robinson, G. Ostrander, H.A. Oxenford, C. Parker, L.P.J.J. Pors, D. Pérez, A. Rodríguez-Ramírez, R. Rodríguez, F. Ruiz-Rentaría, J. Ryan, J.J. Tschirky \& E. Weil. 2002. Status and temporal trends at CARICOMP coral reef sites. Proc. 9th Int. Coral Reef Symp. 1: 325-330.

Carpenter, R.C. \& P.J. Edmunds. 2006. Local and regional scale recovery of Diadema promotes recruitment of scleractinian corals. Ecol. Lett. 9: 268-277.

Cendales, M.H., S. Zea \& J.M. Díaz. 2002. Geomorfología y unidades ecológicas del complejo del complejo de arrecifes de las islas del Rosario y e isla Barú (mar caribe, Colombia). Rev. Acad. Colomb. Cienc. 26: 497-510.

Cho, L.L. \& J.D. Woodley. 2002. Recovery of reefs at Discovery Bay, Jamaica and the role of Diadema antillarum. Proc. 9th Int. Coral Reef Symp. 1: 331-337.

Connell, J.H. 1997. Disturbance and recovery of coral assemblages. Coral Reefs 16: S101-S113.

Connell, J.H., T.P. Hughes \& C.C. Wallace. 1997. A 30-year study of coral abundance, recruitment, and disturbance at several scales in space and time. Ecol. Monogr. 67: 461-488.

Côté, I.M., J.A. Gill, T.A. Gardner \& A.R. Watkinson. 2005. Measuring coral reef decline through metaanalyses. Phil. Trans. R. Soc. B. 360: 385-395.

Díaz, J.M., J. Garzón-Ferreira \& S. Zea. 1995. Los arrecifes coralinos de la Isla de San Andrés. Colombia: estado actual y perspectivas para su conservación. Acad. Colomb. Cien. Exac. Fis. Nat., Colec. Jorge Alvarez Lleras 7, Bogotá, Colombia. 
Díaz, J.M., G. Diaz-Pulido \& J.A. Sánchez. 2000a. Distribution and structure of the Southernmost Caribbean coral reefs: Golfo de Urabá, Colombia. Sci. Mar. 64: 327-336.

Díaz, J.M., L.M. Barrios, M.H. Cendales, J. GarzónFerreira, J. Geister, M. López-Victoria, G.H. Ospina, F. Parra-Velandia, J. Pinzon, B. Vargas-Ángel, F.A. Zapata \& S. Zea. 2000b. Áreas coralinas de Colombia. INVEMAR, Serie de Publicaciones Especiales No. 5, Santa Marta, Colombia.

Diaz-Pulido, G. \& J.M. Díaz. 1997. Algal assemblages in lagoonal reefs of Caribbean oceanic atolls. Proc. 8th Int. Coral Reef Symp. 1: 827-832.

Diaz-Pulido, G. \& J. Garzón-Ferreira. 2002. Seasonality in algal assemblages on upwelling-influenced coral reefs in the Colombian Caribbean. Bot. Mar. 45: 284-292.

Diaz-Pulido, G. \& L.J. McCook. 2002. The fate of bleached corals: patterns and dynamics of algal recruitment. Mar. Ecol. Prog. Ser. 232: 115-128.

Diaz-Pulido, G., J.A. Sánchez, S. Zea, J.M. Díaz \& J. Garzón-Ferreira. 2004. Esquemas de distribución espacial en la comunidad bentónica de arrecifes coralinos continentales y oceánicos del Caribe Colombiano. Rev. Acad. Colomb. Cienc. 28: 337-347.

Done, T.J. 1992. Phase shifts in coral reef communities and their ecological significance. Hydrobiologia 247: 121-132.

Dustan, P. \& J.C. Halas. 1987. Changes in the reef-coral community of Carysfort Reef, Key Largo, Florida: 1974 to 1982 . Coral Reefs 6: 91-106.

Edmunds, P.J. 2002. Long-term dynamics of coral reefs in St. John, US Virgin Islands. Coral Reefs 21: 357367.

Edmunds, P.J. \& R.C. Carpenter. 2001. Recovery of Diadema antillarum reduces macroalgal cover and increases abundance of juvenile corals on a Caribbean reef. P. Natl. Acad. Sci. USA 98: 5067-5071.

Edmunds, P.J. \& R. Elahi. 2007. The demographics of a 15-year decline in cover of the Caribbean reef coral Montastraea annularis. Ecol. Monogr. 77: 3-18.

Ende, C.N. 1993. Repeated-measured analysis: growth and other time-dependent measures, p. 113-137. In S.M. Scheiner \& J. Gurevich (eds.) Design and analysis of ecological experiments. Chapman \& Hall, New Cork, USA.
Friedlander, A., J. Sladek-Nowlis, J.A. Sanchez, R. Appeldoorn, P. Usseglio, C. Mccormick, S. Bejarano $\&$ A. Mitchell-Chui. 2003. Designing effective marine protected areas in old Providence and Santa Catalina Islands, San Andrés Archipelago, Colombia, using biological and sociological information. Conserv. Biol. 17: 1769-1784.

Gardner, T.A., I.M. Côté, J.A. Gill, A. Grant \& A.R. Watkinson. 2003. Long-term region-wide declines in Caribbean corals. Science 301: 958-960.

Gardner, T.A., I.M. Cote, J.A. Gill, A. Grant \& A.R. Watkinson. 2005. Hurricanes and Caribbean coral reefs: Impacts, recovery patterns, and role in longterm decline. Ecology 86: 174-184.

Garzón-Ferreira, J. \& A. Rodríguez-Ramírez. 2010. SIMAC: Development and implementation of a coral reef monitoring network in Colombia. Rev. Biol. Trop. 58 (Suppl. 1): 67-80.

Garzón-Ferreira, J. \& J.M. Díaz. 2003. The Caribbean coral reefs of Colombia, p. 275-301. In J. Cortés (ed.) Latin American coral reefs. Elsevier Science B.V., Amsterdam, The Netherlands.

Garzón-Ferreira, J. \& M. Kielman. 1994. Extensive mortality of corals in the Colombian Caribbean during the last two decades, p. 247-253. In R.N. Ginsburg (ed.) Proceedings of the Colloquium on Global Aspect of Coral Reefs. Health, Hazards and History. RSMAS. University of Miami, Miami, USA.

Garzón-Ferreira, J., D.L. Gil-Agudelo, L.M. Barrios \& S. Zea. 2001. Stony coral diseases observed in southwestern Caribbean reefs. Hydrobiologia 460: 65-69.

Garzón-Ferreira, J., J. Cortés, A. Croquer, H. Guzmán, Z. Leao \& A. Rodríguez-Ramírez. 2004. Southern tropical America: coral reef status and consolidation as GCRMN regional node, p.509-522. In C. Wilkinson (ed.) Status of coral reefs of the world: 2004. AIMS, Townsville, Queensland, Australia.

Garzón-Ferreira, J., M.C. Reyes-Nivia \& A. RodríguezRamírez. 2002. Manual de métodos del SIMAC-Sistema Nacional de Monitoreo de Arrecifes Coralinos en Colombia. INVEMAR, Santa Marta, Colombia.

Garzón-Ferreira, J., S. Zea \& J.M. Díaz. 2005. Incidence of partial mortality and other health indicators in hard coral communities of four southwestern Caribbean atolls. Bull. Mar. Sci. 76: 105-122.

Ginsburg, R.N. (ed.) 1994. Proceedings of the Colloquium on Global Aspect of Coral Reefs. Health, Hazards 
and History. RSMAS. University of Miami, Miami, USA.

Guzman, H.M., R.C. \& J.B.C. Jackson. 2008. Historical decline in coral reef growth after the Panama Canal. Ambio 37: 342-346.

Hallock, P., F.E. Müller-Karger \& J.C. Halas. 1993. Coral reef decline. Natl. Geogr. Res. Explor. 9: 358-378.

Hubbard, D.K. \& D. Scaturo. 1985. Growth rates of seven species of scleractinian corals from Cane Bay and Salt River, St. Croix, USVI. Bull. Mar. Sci. 36: 325-338.

Hughes, T.P. 1989. Community structure and diversity of coral reefs: The role of history. Ecology 70: 275279.

Hughes, T.P. 1994. Catastrophes, phase shifts, and largescale degradation of a Caribbean coral reef. Science 265: $1547-1551$

Hughes, T.P. 1996. Demographic approaches to community dynamics: A coral reef example. Ecology 77 : 2256-2260

Hughes, T.P. \& J.H. Connell. 1999. Multiple stressors on coral reefs: A long-term perspective. Limnol. Oceangr. 44: 932-940.

Hughes, T.P. \& J.E. Tanner. 2000. Recruitment failure, life histories, and long-term decline of Caribbean corals. Ecology 81: 2250-2263.

Hughes, T.P., A.M. Szmant, R. Steneck, R. Carpenter \& S Miller. 1999. Algal blooms on coral reefs: What are the causes?. Limnol. Oceangr. 44: 1583-1586.

Hughes, T.P., A.H. Baird, D.R. Bellwood, M. Card, S.R. Connolly, C. Folke, R. Grosberg, O. Hoegh-Guldberg, J.B.C. Jackson, J. Kleypas, J.M. Lough, P. Marshall, M. Nyström, S.R. Palumbi, J.M. Pandolfi, B. Rosen \& J. Roughgarden. 2003. Climate change, human impacts, and the resilience of coral reefs. Science 301: 929-933.

Jackson, J.B.C. 1997. Reefs since Columbus. Coral Reefs 16: S23-S32.

Jackson, J.B.C., M.X. Kirby, W.H. Berger, K.A. Bjorndal, L.W. Botsford, B.J. Bourque, R.H. Bradbury, R. Cooke, J. Erlandson, J.A. Estes, T.P. Hughes, S. Kidwell, C.B. Lange, H.S. Lenihan, J.M. Pandolfi, C.H. Peterson, R.S. Steneck, M.J. Tegner \& R.R. Warner. 2001. Historical overfishing and the recent collapse of coastal ecosystems. Science 293: 629-638.
Jompa, J. \& L.J. McCook. 2003a. Contrasting effects of turf algae on corals: massive Porites spp. are unaffected by mixed-species turfs, but killed by the red alga Anotrichium tenue. Mar. Ecol. Prog. Ser. 258: 79-86.

Jompa, J. \& L.J. McCook. 2003b. Coral-algal competition: macroalgae with different properties have different effects on corals. Mar. Ecol. Prog. Ser. 258: 87-95.

Kramer, P.A. 2003. Synthesis of coral reef health indicators for the Western Atlantic: Results of the AGRRA Program (1997-2000). Atoll Res. Bull. 496: 1-57.

Liddell, W.D. \& S.L. Ohlhorst. 1993. Ten years of disturbance and change on a Jamaican fringing reef. Proc. 7th Int. Coral Reef Symp. 1: 144-150.

Linton, D. \& T. Fisher (eds.) 2004. CARICOMP. Caribbean Coastal Marine Productivity Program. 1993-2003. CARICOMP, University of the West Indies, Mona, Kingston, Jamaica.

López-Victoria, M. \& J.M. Díaz. 2000. Morfología y estructura de las formaciones coralinas del archipiélago de San Bernardo, Caribe colombiano. Rev. Acad. Colomb. Cienc. 24: 219-230.

López-Londoño, T., R. Navas-Camacho \& D. Gil-Agudelo. 2007. Corales escleractínios juveniles como evidencia del mantenimiento y renovación de las formaciones coralinas en el archipiélago de las Islas del Rosario, p. 73-77. In INVEMAR (ed.) Informe del Estado de los Ambientes Marinos y Costeros en Colombia: Año 2006. INVEMAR, Santa Marta, Colombia.

Martínez, S. \& A. Acosta. 2005. Cambio temporal en la estructura de la comunidad coralina del área de Santa Marta-Parque Nacional Natural Tayrona (Caribe colombiano). Bol. Invest. Mar. Cost. 34: 161-191.

McClanahan, T.R. \& N.A. Muthiga, 1998. An ecological shift in a remote coral atoll of Belize over 25 years. Environ. Conserv. 25: 122-130.

McClanahan, T.R., R.B. Aronson, W.F. Precht \& N.A. Muthiga. 1999. Fleshy algae dominate remote coral reefs of Belize. Coral Reefs 18: 61-62.

McCook, L.J. 2001. Competition between corals and algal turfs along a gradient of terrestrial influence in the nearshore central Great Barrier Reef. Coral Reefs 19: 419-425.

McCook, L.J., J. Jompa \& G. Diaz-Pulido. 2001. Competition between corals and algae on coral reefs: a review of evidence and mechanisms. Coral Reefs 19: 400-417. 
Milliken, G.A. \& D.E. Johnson. 1992. Analysis of Messy Data. Volume I: Designed Experiments. Chapman \& Hall, New York, USA.

Mumby, P.J., C.P. Dahlgren, A.R. Harborne, C.V. Kappel, F. Micheli, D.R. Brumbaugh, K.E. Holmes, J.M. Mendes, K. Broad, J.N. Sanchirico, K. Buch, S. Box, R.W. Stoffle \& A.B. Gill. 2006. Fishing, trophic cascades, and the process of grazing on coral reefs. Science 311: 98-101.

Navas, R., D. L. Gil-Agudelo, A. Rodríguez-Ramírez, C. Reyes-Nivia \& J. Garzón-Ferreira. 2010. Coral diseases and bleaching on Colombian Caribbean coral reefs. Rev. Biol. Trop. 58 (Suppl. 1): 95-106.

Nyström, M., C. Folke \& F. Moberg. 2000. Coral reef disturbance and resilience in a human-dominated environment. Trend Ecol. Evol. 15: 413-417.

Pandolfi, J.M. \& J.B.C. Jackson. 2006. Ecological persistence interrupted in Caribbean coral reefs. Ecol. Lett. 9: 818-826.

Pandolfi, J.M., R.H. Bradbury, E. Sala, T.P. Hughes, K.A. Bjorndal, R.G. Cooke, D. McArdle, L. McClenachan, M.J.H. Newman, G. Paredes, R.R. Warner \& J.B.C. Jackson. 2003. Global trajectories of the long-term decline of coral reef ecosystems. Science 301: 955957.

Pizarro, V., J. Polania \& J.C. Thomason. 2007. Recruitment and juvenile survivorship of brain corals at San Andres Island, Western Caribbean Sea. Cah. Biol. Mar. 48: 113-119.

Porter, J.W. \& O.W. Meier. 1992. Quantification of loss and change in Floridian reef coral populations. Am. Zool. 32: 625-640.

Potvin, C. 1993. ANOVA: experiments in controlled environments, p. 46-68. In S.M. Scheiner \& J. Gurevich (eds.) Design and analysis of ecological experiments. Chapman \& Hall, New York, USA.

Rodríguez-Ramírez, A. \& J. Garzón-Ferreira. 2003. Monitoreo de arrecifes coralinos, pastos marinos y manglares en la Bahía de Chengue (Caribe Colombiano): 1993-1999. INVEMAR, Serie de Publicaciones Especiales No.8, Santa Marta, Colombia.

Rodríguez-Ramírez, A., M.C. Reyes-Nivia, R. NavasCamacho, S. Bejarano, J. Garzón-Ferreira \& F Zapata. 2006. Status of the coral reefs of Colombia in 2003. Proc. 10th Int. Coral Reef Symp.: 976-981.

Rodríguez-Ramírez, A., C. Bastidas, J. Cortés, H. Guzmán, Z. Leão, J. Garzón-Ferreira, R. Kikuchi, B. PadovaniFerreira, J.J. Alvarado, C. Jiménez, A.C. Fonseca,
E. Salas, J. Nivia, C. Fernández, S. Rodríguez, D. Debrot, A. Croquer, D. Gil, D.I. Gómez, R. NavasCamacho, M.C. Reyes-Nivia, A. Acosta, E. Alvarado, V. Pizarro, A. Sanjuan, P. Herrón, F.A. Zapata, S. Zea, M. López-Victoria \& J.A. Sánchez. 2008a. Status of coral reefs and associated ecosystems in Southern Tropical America: Brazil, Colombia, Costa Rica, Panamá and Venezuela, p. 281-294. In Wilkinson, C. (ed.) Status of coral reefs of the world: 2008. Global coral reef monitoring network and Reef and Rainforest Research Centre, Townsville, Australia.

Rodríguez-Ramírez, A., C. Bastidas, S. Rodríguez, Z. Leão, R. Kikuchi, M. Oliveira, D. Gil, J. GarzónFerreira, M.C. Reyes-Nivia, R. Navas-Camacho, N. Santodomingo, G. Diaz-Pulido, D. Venera-Ponton, L. Florez-Leiva, A. Rangel-Campo, C. Orozco, J.C. Márquez, S. Zea, M. López-Victoria, J.A. Sánchez \& M.C. Hurtado. 2008b. The effects of coral bleaching in the Southern Tropical America: Brazil, Colombia, and Venezuela, p. 105-114. In C. Wilkinson \& D. Souter (eds.) Status of Caribbean Coral Reefs after the Bleaching and Hurricanes of 2005. GCRMN and RRRC, Townsville, Australia.

Rogers, C.S. \& J. Miller. 2006. Permanent 'phase shifts' or reversible declines in coral cover? Lack of recovery of two coral reefs in St. John, US Virgin Islands. Mar. Ecol. Prog. Ser. 306: 103-114.

Sánchez J.A., S. Herrera, R. Navas-Camacho, A. Rodríguez-Ramírez, P. Herron, V. Pizarro, A.R. Acosta, P.A. Castillo, P. Montoya \& C. Orozco. 2010. White plague-like coral disease in remote reefs of the Western Caribbean. Rev. Biol. Trop. 58 (Supl. 1): 145-154.

Sánchez, J.A., V. Pizarro, A.R. Acosta, P.A. Castillo, P. Herrón, J.C. Martínez, P. Montoya \& C. Orozco. 2005. Evaluating coral reef benthic communities in remote Caribbean atolls (Quitasueño, Serrana, and Roncador Banks) to recommend Marine-Protected Areas for the SeaFlower Biosphere Reserve. Atoll Res. Bull. 531: 1-65.

Shulman, M.J. \& D.R. Robertson. 1996. Change in the coral reefs of San Blas, Caribbean Panama: 1983 to 1990. Coral Reefs 15: 231-236.

Somerfield, P.J., W.C. Jaap, K.R. Clarke, M. Callahan, K. Hackett, J. Porter, M. Lybolt, C. Tsokos \& G. Yanev. 2008. Changes in coral reef communities among the Florida Keys, 1996-2003. Coral Reefs 27: 951-965.

Sutherland, K.P., J.W. Porter \& C. Torres. 2004. Disease and immunity in Caribbean and Indo-Pacific zooxanthellate corals. Mar. Ecol. Prog. Ser. 266: 273-302. 
Szmant, A. 2002. Nutrient enrichment on coral reefs: Is it a major cause of coral reef decline?. Estuaries 25: 743-766.

Sokal, R.R. \& F.J. Rolf. 1995. Biometry: The principles and practice of statistics in biological research. Freeman, New York, USA.

Vidal, A.M., C.M. Villamil \& A. Acosta. 2005. Composición y densidad de corales juveniles en dos arrecifes profundos de San Andrés isla, Caribe colombiano. Bol. Invest. Mar. Cost. 34: 211-225.

Williams, I.D. \& N.V.C. Polunin. 2001. Large-scale associations between macroalgal cover and grazer biomass on mid-depth reefs in the Caribbean. Coral Reefs 19: 358-366.

Williams, I.D., N.V.C. Polunin \& V.J. Hendrick. 2001. Limits to grazing by herbivorous fishes and the impact of low coral cover on macroalgal abundance on a coral reef in Belize. Mar. Ecol. Prog. Ser. 222: 187-196.

Zar, J.H. 1999. Biostatistical analysis. Prentice Hall, Upper Saddle River, USA.

Zea, S. 1993. Cover sponge and other sessile organism in rocky and coral reef habitats of Santa Marta, Colombian Caribbean Sea. Carib. J. Sci. 29: 75-88.

Zea, S. 1994. Patterns of coral and sponge abundance in stressed coral reefs at Santa Marta, Colombian Caribbean, p. 257-264. In R.W.M Van Soest, T.M.G. Van Kempen \& J.C. Braekman (eds.) Sponge in time and space. Biology, Chemistry, Paleontology. Balkema, Rotterdam, Amsterdam, The Netherlands.

Zea, S., J. Geister, J. Garzón-Ferreira \& J.M. Díaz. 1998. Biotic changes in the reef complex of San Andrés Island (Southwestern Caribbean Sea, Colombia) occurring over nearly three decades. Atoll Res. Bull. 456: 1-30. 
